(C) The Authors 2020. This is an Open Access article, distributed under the terms of the Creative Commons Attribution licence (http:// creativecommons.org/licenses/by/4.0/), which permits unrestricted re-use, distribution, and reproduction in any medium, provided the original work is properly cited.

\title{
Dietary inclusion of Antarctic krill meal during the finishing feed period improves health and fillet quality of Atlantic salmon (Salmo salar L.)
}

\author{
Turid Mørkøre ${ }^{1,2 *}$, Helena M. Moreno ${ }^{3}$, Javier Borderías ${ }^{3}$, Thomas Larsson ${ }^{1}$, Hege Hellberg ${ }^{4}$, \\ Bjarne Hatlen ${ }^{1}$, Odd Helge Romarheim ${ }^{1}$, Bente Ruyter ${ }^{1}$, Carlo C. Lazado ${ }^{5}$, Raúl Jiménez-Guerrero ${ }^{1}$, \\ Målfrid T. Bjerke ${ }^{1}$, Tibiabin Benitez-Santana ${ }^{6}$ and Aleksei Krasnov ${ }^{5}$ \\ ${ }^{1}$ Department of Nutrition and Feed Technology, Nofima (Norwegian Institute of Food, Fisheries and Aquaculture Research), NO- \\ 9291 Tromsø, Norway \\ ${ }^{2}$ Department of Animal and Aquacultural Sciences, Faculty of Biosciences, Norwegian University of Life Sciences, NO-1432 As, \\ Norway \\ ${ }^{3}$ Products Department, Institute of Food Science Technology and Nutrition, ICTAN-CSIC, 28040 Madrid, Spain \\ ${ }^{4}$ Fish Vet Group, Benchmark Norway AS, O218 Oslo, Norway \\ ${ }^{5}$ Department of Fish Health, Nofima (Norwegian Institute of Food, Fisheries and Aquaculture Research), NO-9291 Tromsø, \\ Norway \\ ${ }^{6}$ Innovation Department, Aker BioMarine AS, NO-1327 Lysaker, Norway
}

(Submitted 2 October 2019 - Final revision received 27 January 2020 - Accepted 10 March 2020 - First published online 7 April 2020)

Abstract

There is an urgent need to find alternative feed resources that can further substitute fishmeal in Atlantic salmon diets without compromising health and food quality, in particular during the finishing feeding period when the feed demand is highest and flesh quality effects are most significant. This study investigates efficacy of substituting a isoprotein (35\%) and isolipid (35\%) low fishmeal diet (FM, $15 \%$ ) with Antarctic krill meal (KM, $12 \%$ ) during 3 months with growing finishing $2.3 \mathrm{~kg}$ salmon (quadruplicate sea cages/diet). Final body weight (3.9 (sE 0.04$) \mathrm{kg}$ ) was similar in the dietary groups, but the KM group had more voluminous body shape, leaner hearts and improved fillet integrity, firmness and colour. Ectopic epithelial cells and focal Ca deposits in intestine were only detected in the FM group. Transcriptome profiling by microarray of livers showed dietary effects on several immune genes, and a panel of structural genes were up-regulated in the KM group, including cadherin and connexin. Up-regulation of genes encoding myosin heavy chain proteins was the main finding in skeletal muscle. Morphology examination by scanning electron microscopy and secondary structure by Fourier transform IR spectroscopy revealed more ordered and stable collagen architecture of the KM group. NEFA composition of skeletal muscle indicated altered metabolism of $n-3, n-6$ and SFA of the KM group. The results demonstrated that improved health and meat quality in Atlantic salmon fed krill meal were associated with up-regulation of immune genes, proteins defining muscle properties and genes involved in cell contacts and adhesion, altered fatty acid metabolism and fat deposition, and improved gut health and collagen structure.

\section{Key words: Aquafeeds: Krill: Health: Metabolism: Connective tissue}

Wild fish harvested from the ocean and reduced into fishmeal and fish oil are finite resources that are shared across a range of users with increasing demands, from direct human consumption, pig and poultry production and to aquaculture feeds ${ }^{(1,2)}$. As a consequence of high costs of fishmeal and fish oil, traditional small pelagic fish have been increasingly replaced by vegetable feed ingredients in salmon feeds during the past two decades, from 65 to $18 \%$ for fishmeal and from 24 to $11 \%$ for fish oil ${ }^{(3)}$. However, farmed salmon is still a main user of fishmeal and fish oil ${ }^{(1)}$; hence, further complementing feed ingredients from wild fish is required to support continued growth. The average weight of salmon at harvesting is $4-5 \mathrm{~kg}^{(4)}$, and it is particularly important to identify feed ingredients that can replace fishmeal and fish oil during the finishing feeding period when the feed demand is highest. It is, however, vital that fishmeal and fish oil replacers not only promote similar growth and survival rates to traditional marine aquafeed ingredients but also ensure that aquatic animal health and welfare is fostered and that the resultant aquaculture products are nutritionally excellent, safe to eat and accepted by the consuming public ${ }^{(2)}$.

Abbreviations: ALT, alanine aminotransferase; FA, fatty acid; FM, fish meal; KM, krill meal; NQC, Norwegian Quality Cut; PC, pyloric caeca; PL, phospholipid; VF, visceral fat.

* Corresponding author: Turid Mørkøre, fax +47 64965101, email turid.morkore@nmbu.no 
Antarctic krill (Euphausia superba) is a small marine crustacean organism that has generated strong research interest during the past several years ${ }^{(5)}$. Based on the nutritional profile, krill has been specified with protein, amino acids and ash contents which are comparable to that of fish ${ }^{(6,7)}$. Noteworthy are also the relatively high levels of EPA and $\mathrm{DHA}^{(8)}$, phospholipids (PL), vitamins, nucleotides and astaxanthin of krill meal ${ }^{(9)}$. Krill living in the Southern Ocean is considered a sustainable source of protein in aquafeeds ${ }^{(10)}$, and studies with carnivorous fish including Atlantic salmon have documented that krill meal may facilitate efficient reduction in the use of fishmeal in high fishmeal diets ${ }^{(11-16)}$. For example, there are positive effects documented on feed intake and growth at different life stages without compromising fillet quality. However, previous studies have mainly used small fish $(<2 \mathrm{~kg})$ and fishmeal as the major dietary protein source. Studies with krill meal supplemented to plant-based/low fishmeal diets, representing the current industrial practice ${ }^{(3,17)}$, and fed to fish reaching normal slaughter weight, are warranted. Furthermore, underlying mechanisms by which krill meal affects fish health and fillet quality are still poorly understood.

As the physical, nutritional and sensory properties of salmon meat at the point of human consumption are influenced by the dietary raw materials ${ }^{(18,19)}$, it is important to monitor and understand the effects on fillet quality when novel feed ingredients such as krill meal are introduced. Thus, improved knowledge is required on the effect of feed resources alternative to forage fish during the finishing period before harvesting when the impact on major salmon flesh quality properties is significant ${ }^{(20,21)}$. For example, the typical pink to deep red colour, fillet firmness and fillet integrity are major quality criteria that dictate the market value of salmon fillets ${ }^{(22,23)}$.

The present study investigates health parameters and meat quality of Atlantic salmon fed a diet where fishmeal was substituted with krill meal during the finishing feeding period with the overarching goal to improve the systemic understanding of dietary krill meal effects on a biochemical, morphological and molecular level.

\section{Material and methods}

\section{Animal welfare}

The experiment was performed according to the guidelines and protocols approved by the European Union (EU Council 86/609; D.L. 27.01.1992, no. 116) and by the National Guidelines for Animal Care and Welfare published by the Norwegian Ministry of Education and Research.

\section{Experimental design and animal management}

The fish used were 800 Atlantic salmon (Salmo salar L.; S0 smolt, $16 \mathrm{G}$, AquaGen) with an initial weight of $2270 \mathrm{~g}$ (sD $27 \mathrm{~g}$ ). The salmon were randomly distributed into eight $125 \mathrm{~m}^{3}$ sea cages at The LetSea feed trial unit in Norway, Dønna county in Northern Norway (100 fish in each sea cage) and fed isoprotein (35\%) and isolipid (35\%) $9 \mathrm{~mm}$ feed with $15 \%$ fishmeal (FM group) or a diet where fishmeal was partly substituted by $12 \%$ Antarctic krill meal (KM group; Qrill ${ }^{\mathrm{TM}}$
Aqua; Aker BioMarine Antarctic AS). The feeds were produced at the Feed Technology Center of Nofima in Titlestad, Norway, formulated to meet known nutritional requirements of salmonid fish ${ }^{(24)}$ and balanced for EPA and DHA content. The FM and KM diets were analysed for moisture (drying at $103^{\circ} \mathrm{C}$ to stable weight; ISO 6496:1999), crude fat (Soxhlet, with acid hydrolysis; EC 152/2009), crude protein (Nx6.25, Kjeltech Auto System; Tecator), ash (combustion at $550^{\circ} \mathrm{C}$, ISO 5984:2002), starch ${ }^{(25)}$, astaxanthin ${ }^{(26)}$ and gross energy (bomb calorimetry; ISO 9831:1998). Additionally, the composition of amino acids (ISO 13903:2005, EU 152/2009; tryptophan EU 152/2009) in the feeds and fatty acid (FA) composition of the feeds and oils ${ }^{(27)}$ were analysed. Formulation and chemical composition of the experimental diets are shown in Table 1. The composition of the fishmeal was: water $8.1 \%$, protein $69.3 \%$, lipid $8.5 \%$ and ash $16.6 \%$. The composition of the krill meal was: water $7.0 \%$, protein $55 \%$, lipid $31 \%$ and ash $8 \%$. The FA composition of the fishmeal, krill meal, fish oil, rapeseed oil, FM and KM diets and fillets is presented in Table 2, and the FA composition of lipid classes and the amino acid composition of the diets are presented in Tables 3 and 4, respectively.

Each of the feeds was fed by automatic feeders (S1, Betten) to quadruplicate sea cages during $90 \mathrm{~d}$ (September-December 2017), two meals per $d$. The sea cages were equipped with a

Table 1. Formulation and chemical composition of the experimental feeds used in the present study: a low fishmeal diet (FM) and the same diet with fishmeal partly substituted by Antarctic krill meal (KM)* (Percentages)

\begin{tabular}{|c|c|c|}
\hline & FM feed & KM feed \\
\hline \multicolumn{3}{|l|}{ Diet formulation (\%) } \\
\hline LT fishmeal & 15 & 5 \\
\hline Krill meal (Aker Biomarine) & 0 & 12 \\
\hline Wheat (Norgesmøllene) & 10 & 10 \\
\hline Wheat gluten (Tereos) & 10 & 10 \\
\hline Soya protein concentrate (Agrokorn) & 14 & 14 \\
\hline Horse beans (Tereos) & 6 & 6 \\
\hline Soya lecithin (Denofa) & 1 & 1 \\
\hline Maize gluten (Agrokorn) & 3 & 3 \\
\hline Fish oil (Vedde, Norway) & 12 & 8 \\
\hline Rapeseed oil (Emmelev) & 21 & 22 \\
\hline Minerals (Vilomix) & 0.6 & 0.6 \\
\hline Vitamins (Vilomix) & 2 & 2 \\
\hline Monosodium phosphate (Vilomix) & $2 \cdot 6$ & $2 \cdot 6$ \\
\hline Carophyll Pink (10\% Astax) (Vilomix)† & 0.05 & 0.05 \\
\hline Vitamin A (retinol) (IU/g) (Vilomix) & $46 \cdot 4$ & 29.5 \\
\hline Ytrium oxide (VWR) & 0.01 & 0.01 \\
\hline Choline chloride (Vilomix) & 0.5 & 0.5 \\
\hline DL-Methionine (Vilomix) & 0.9 & 0.9 \\
\hline L-Lysine (Vilomix) & 1.7 & 1.7 \\
\hline L-Threonine (Vilomix) & 0.4 & 0.4 \\
\hline \multicolumn{3}{|l|}{ Chemical composition (\%) } \\
\hline Crude protein & 35.5 & $35 \cdot 6$ \\
\hline Crude lipids & $34 \cdot 2$ & 34.6 \\
\hline Starch & $11 \cdot 2$ & $11 \cdot 3$ \\
\hline Ash & $7 \cdot 0$ & $6 \cdot 7$ \\
\hline Water & $6 \cdot 1$ & $6 \cdot 0$ \\
\hline Energy (MJ/kg) & $24 \cdot 2$ & $24 \cdot 6$ \\
\hline
\end{tabular}

* The fishmeal, krill meal (Aker BioMarine's krill fishery) has been certified by the Marine Stewardship Council (MSC) as being sustainable and $100 \%$ traceable.

† Free astaxanthin analysed in diet was 46 and $48 \mathrm{mg} / \mathrm{kg}$ in the FM and KM feed, respectively. The krill meal contained $<0.2 \mathrm{mg} / \mathrm{kg}$ free astaxanthin and $35 \mathrm{mg} / \mathrm{kg}$ astaxanthin esters. 
Table 2. Selected fatty acids (\% of total fatty acids) of the fishmeal, krill meal, fish oil, rapeseed oil, FM and KM feed, and fillets of Atlantic salmon fed the different diets (Mean values, with standard errors for fillet)

\begin{tabular}{|c|c|c|c|c|c|c|c|c|c|c|}
\hline & \multirow[b]{2}{*}{ FM } & \multirow[b]{2}{*}{ Krill meal } & \multirow[b]{2}{*}{ Fish oil } & \multirow[b]{2}{*}{ Rapeseed oil } & \multirow[b]{2}{*}{ FM feed } & \multirow[b]{2}{*}{$\mathrm{KM}$ feed } & \multicolumn{2}{|c|}{ FM fillet } & \multicolumn{2}{|c|}{ KM fillet } \\
\hline & & & & & & & Mean & $\mathrm{SE}$ & Mean & SE \\
\hline $14: 0$ & 3.2 & 8.3 & 7.4 & $<0.1$ & 2.6 & 2.6 & 2.3 & 0.0 & 2.4 & 0.0 \\
\hline $16: 0$ & $12 \cdot 6$ & $17 \cdot 1$ & $12 \cdot 2$ & 4.9 & 8.2 & 8.5 & 9.6 & 0.1 & 9.7 & 0.1 \\
\hline $18: 0$ & $2 \cdot 0$ & 0.8 & 1.4 & 1.5 & 1.7 & 1.7 & $2 \cdot 3$ & 0.0 & $2 \cdot 3$ & 0.0 \\
\hline $16: 1$ & 3.5 & 3.1 & 3.9 & 0.2 & 1.8 & 1.7 & $2 \cdot 2$ & 0.0 & $2 \cdot 2$ & 0.0 \\
\hline $18: 1$ & 13.9 & 14.4 & 11.9 & $66 \cdot 0$ & $42 \cdot 3$ & 44.3 & 41.9 & 0.1 & $42 \cdot 8^{*}$ & 0.1 \\
\hline $20: 1$ & 7.9 & 1.0 & 11.6 & 1.2 & 6.8 & 4.8 & $5 \cdot 2$ & 0.0 & $4.8^{*}$ & 0.0 \\
\hline $22: 1$ & 9.4 & 0.5 & 18.8 & 0.2 & 7.3 & $5 \cdot 3$ & $5 \cdot 0$ & 0.1 & $4 \cdot 2^{*}$ & 0.1 \\
\hline $18: 2 n-6$ & 0.9 & 1.2 & 1.3 & 20.5 & 14.4 & $15 \cdot 1$ & $13 \cdot 6$ & 0.1 & $13 \cdot 8^{*}$ & 0.1 \\
\hline $18: 3 n-3$ & 0.1 & 0.1 & $1 \cdot 1$ & $9 \cdot 2$ & 6.0 & 6.4 & $5 \cdot 2$ & 0.0 & $5 \cdot 3$ & 0.0 \\
\hline $20: 5 n-3$ & 6.4 & 11.2 & 6.4 & $<0.1$ & 2.5 & $2 \cdot 8$ & 2.3 & 0.0 & $2 \cdot 4^{*}$ & 0.0 \\
\hline $22: 6 n-3$ & $12 \cdot 7$ & 8.1 & 8.5 & $<0.1$ & 3.5 & $3 \cdot 1$ & 3.9 & 0.0 & $3 \cdot 7^{\star}$ & 0.1 \\
\hline $\mathrm{EPA}+\mathrm{DHA}$ & 19.1 & $19 \cdot 3$ & 14.9 & $<0.1$ & 6.0 & 5.9 & $6 \cdot 2$ & 0.0 & $6 \cdot 1$ & 0.1 \\
\hline Sum $n-0$ & 17.9 & $26 \cdot 2$ & 21.3 & $7 \cdot 2$ & 13.4 & 13.7 & 14.8 & 0.1 & $15 \cdot 1$ & 0.1 \\
\hline Sum $n-1$ & 35.9 & $19 \cdot 0$ & 46.9 & 67.7 & $57 \cdot 2$ & $56 \cdot 1$ & 54.8 & 0.1 & $54.5^{\star}$ & 0.1 \\
\hline Sum $n-6$ & 1.9 & 1.6 & $2 \cdot 0$ & 20.5 & 14.8 & 15.5 & $15 \cdot 1$ & 0.1 & $15 \cdot 4$ & 0.1 \\
\hline Sum $n-3$ & 22.5 & $27 \cdot 3$ & 20.9 & 9.2 & 12.5 & $12 \cdot 8$ & $13 \cdot 0$ & 0.1 & $13 \cdot 1$ & 0.1 \\
\hline
\end{tabular}

* Significant difference $(P<0.05)$ between the dietary groups for that parameter.

† A low fishmeal diet (FM), or the same diet with fishmeal partly substituted by krill meal (KM).

Table 3. Relative fatty acid composition by lipid class: TAG, mono- and diacylglycerols (MAG), phospholipids (PL) and NEFA of feed given to the Atlantic salmon in the present study*

(Percentages of total fatty acids)

\begin{tabular}{|c|c|c|c|c|c|c|c|c|}
\hline & \multicolumn{2}{|c|}{ TAG } & \multicolumn{2}{|c|}{ MAG } & \multicolumn{2}{|c|}{ PL } & \multicolumn{2}{|c|}{ NEFA } \\
\hline & FM & $\mathrm{KM}$ & FM & $\mathrm{KM}$ & FM & $\mathrm{KM}$ & FM & $\mathrm{KM}$ \\
\hline Total & $91 \cdot 2$ & 89.2 & 2.5 & 2.4 & $2 \cdot 6$ & 5 & 3.8 & 3.4 \\
\hline $14: 0$ & $2 \cdot 7$ & 2.7 & $3 \cdot 1$ & $3 \cdot 2$ & ND & 1.9 & $2 \cdot 7$ & $2 \cdot 1$ \\
\hline $16: 0$ & $7 \cdot 8$ & 7.7 & $10 \cdot 2$ & $10 \cdot 1$ & 20 & $23 \cdot 1$ & 14.6 & $15 \cdot 1$ \\
\hline $18: 0$ & 1.6 & 1.7 & 2 & 1.6 & 3.1 & 1.7 & 2.5 & 2.4 \\
\hline $20: 0$ & 0.5 & 0.5 & 0.6 & 0.4 & 0.2 & 0.1 & 0.3 & 0.3 \\
\hline $18: 3 n-3$ & $5 \cdot 8$ & $6 \cdot 2$ & $4 \cdot 1$ & 4.5 & 3.4 & 3.4 & 3.6 & 4 \\
\hline $20: 5 n-3$ & 2 & 1.6 & 2 & 4.4 & $2 \cdot 2$ & 13.6 & 3.9 & $6 \cdot 4$ \\
\hline $22: 5 n-3$ & 0.3 & 0.2 & 0.7 & 0.2 & 0.3 & 0.4 & 0.5 & 0.4 \\
\hline $22: 6 n-3$ & 2.5 & 1.9 & 2.7 & 3.3 & 5.4 & 9.6 & $7 \cdot 6$ & 8.6 \\
\hline $18: 2 n-6$ & $13 \cdot 3$ & $14 \cdot 3$ & $13 \cdot 3$ & $13 \cdot 6$ & $36 \cdot 1$ & $20 \cdot 1$ & $18 \cdot 2$ & $19 \cdot 6$ \\
\hline $20: 2 n-6$ & 0.1 & 0.1 & 0.2 & 0.2 & 0.2 & 0.1 & ND & 0.1 \\
\hline $20: 4 n-6$ & ND & ND & ND & ND & ND & ND & ND & ND \\
\hline $18: 1 n-7$ & $2 \cdot 7$ & 2.9 & $2 \cdot 6$ & 3.4 & 2 & 4.5 & 2.5 & 3 \\
\hline $22: 1 n-7$ & 0.2 & 0.2 & 0.5 & 0.3 & 0.1 & 0.3 & 0.4 & 0.4 \\
\hline $16: 1 n-9$ & 0.2 & 0.1 & ND & ND & 0.1 & 0.1 & 0.1 & 0.1 \\
\hline $18: 1 n-9$ & $42 \cdot 2$ & $45 \cdot 2$ & 36 & $35 \cdot 3$ & $16 \cdot 7$ & 11 & 23.7 & 22.6 \\
\hline $20: 1 n-9$ & $4 \cdot 6$ & 3.6 & $4 \cdot 1$ & $3 \cdot 1$ & 1.4 & 0.8 & $3 \cdot 2$ & 2.5 \\
\hline $24: 1 n-9$ & 0.4 & 0.3 & 0.5 & 0.3 & 1.2 & 0.3 & 0.3 & 0.1 \\
\hline $18: 1 n-11$ & 0.1 & 0.2 & $2 \cdot 4$ & 0.2 & 0.1 & ND & 0.3 & 0.3 \\
\hline $20: 1 n-11$ & 1 & 1 & 0.8 & $1 \cdot 2$ & 0.4 & 1.8 & $1 \cdot 2$ & 1.6 \\
\hline $22: 1 n-11$ & $6 \cdot 7$ & $4 \cdot 8$ & $6 \cdot 4$ & 4.5 & $1 \cdot 3$ & 0.5 & 4 & 3 \\
\hline $\mathrm{EPA}+\mathrm{DHA}$ & 4.5 & 3.4 & $4 \cdot 6$ & $7 \cdot 8$ & $7 \cdot 6$ & $23 \cdot 2$ & 11.6 & 15 \\
\hline Sum $n-3$ & $11 \cdot 2$ & $10 \cdot 2$ & 10 & $12 \cdot 9$ & 12 & 27.5 & $16 \cdot 7$ & $20 \cdot 1$ \\
\hline Sum $n-6$ & $13 \cdot 7$ & $14 \cdot 6$ & $14 \cdot 1$ & 13.9 & $36 \cdot 3$ & $20 \cdot 1$ & $18 \cdot 3$ & $19 \cdot 8$ \\
\hline Sum $n-0$ & $13 \cdot 3$ & $13 \cdot 2$ & $16 \cdot 1$ & $15 \cdot 8$ & $24 \cdot 2$ & $27 \cdot 4$ & $21 \cdot 1$ & 20.5 \\
\hline
\end{tabular}

ND, not detected (less than $0.05 \%$ ).

${ }^{*} \mathrm{~A}$ low fishmeal diet (FM), or the same diet with fishmeal partly substituted by krill meal (KM).

feed collecting system (LiftUP, Lift Up AS) to facilitate accurate calculation of the feed consumption and feed conversion ratio, aiming at an overfeeding of 5-10\%. Feed intake per sea cage was registered weekly, as the difference between feed amount and feed spill collected at the bottom of the sea cage, using the feed collecting system. During the period 16 October-23 October, all sea cages were fed Slice ${ }^{\circledR}$ (Skretting), a chemotherapeutant for treating sea lice outbreaks on salmon farms. Before harvesting, the fish were starved for $4 \mathrm{~d}$.

\section{Slaughter and registrations}

All fish within each sea cage were anaesthetised using Finquel vet. (Tricaine Methanesulfonate; Scanvacc) and bulk weighed 
Table 4. Amino acid composition ( $\mathrm{g} / 100 \mathrm{~g}$ ) of the fishmeal (FM) feed and krill meal (KM) feed and of collagen extracted from skeletal muscle of Atlantic salmon fed the experimental feeds

(Mean values)

\begin{tabular}{lrrcc}
\hline $\begin{array}{l}\text { Amino acid/organic } \\
\text { acid }\end{array}$ & $\begin{array}{r}\text { FM } \\
\text { feed }\end{array}$ & $\begin{array}{c}\text { KM } \\
\text { feed }\end{array}$ & $\begin{array}{c}\text { FM } \\
\text { collagen* }\end{array}$ & $\begin{array}{c}\text { KM } \\
\text { collagen* }\end{array}$ \\
\hline Alanine & 1.56 & 1.35 & 0.07 & 0.07 \\
Arginine & 1.87 & 1.68 & 0.03 & 0.03 \\
Asparagine & 2.71 & 2.46 & 0.04 & 0.04 \\
Cysteine + cystine & 0.48 & 0.43 & $<0.01$ & $<0.01$ \\
Glutamic acid (total) & 7.14 & 6.69 & 0.05 & 0.06 \\
Glycine & 1.54 & 1.27 & 0.19 & 0.20 \\
Histidine & 0.70 & 0.68 & 0.01 & 0.01 \\
Hydroxyproline & 0.13 & 0.17 & 0.04 & 0.03 \\
Isoleucine & 1.32 & 1.29 & 0.01 & 0.01 \\
Leucine & 2.56 & 2.40 & 0.02 & 0.02 \\
Lysine & 3.03 & 2.84 & 0.02 & 0.02 \\
Methionine & 1.47 & 1.45 & 0.01 & 0.01 \\
Ornithin & $<0.05$ & $<0.05$ & $\mathrm{ND}$ & $\mathrm{ND}$ \\
Phenylalanine & 1.61 & 1.52 & 0.01 & 0.01 \\
Proline & 2.26 & 2.09 & 0.06 & 0.06 \\
Serine & 1.58 & 1.46 & 0.03 & 0.03 \\
Taurine & 0.17 & 0.13 & $\mathrm{ND}$ & $\mathrm{ND}$ \\
Threonine & 1.54 & 1.43 & 0.02 & 0.02 \\
Tryptophan & 0.35 & 0.36 & $\mathrm{ND}$ & $\mathrm{ND}$ \\
Tyrosine & 1.14 & 1.09 & 0.01 & 0.01 \\
Valine & 1.45 & 1.36 & 0.02 & 0.01 \\
\hline "Consdeng & &
\end{tabular}

${ }^{*}$ Considering $0.66 \%$ collagen in Atlantic salmon muscle ${ }^{(41)}$. Determinations were performed in triplicate and data correspond to mean values. Standard deviations were in all cases lower than $5 \%$. Aspartic acid and hydroxylysine were not detected.

at the start and termination of the experiment. At the end of the trial, twenty fish were randomly selected from each sea cage for analyses. The first five fish were sampled for blood analyses and subsequent gene expression and histopathological examination. After anaesthesia and blood sampling, the fish were killed by percussive stunning and bled for $20 \mathrm{~min}$ in a tank with running seawater (ambient temperature), after sectioning the left gill arch.

Each fish was scored for eye opacity on a scale from 0 to 4 , where score 0 represents no visible opacity and score 4 represents opacity of more than $75 \%$ of the cross-sectional area of the lens (complete cataract) ${ }^{(28)}$. The colour of the livers was scored according to a scale from 1 to 5 , where score 1 is pale/yellowish and score 5 is dark brown (Fig. 1(a)). Amount of visceral fat (VF) was similarly scored from 1 to 5 according to the visibility of pyloric caeca (PC), where score 1: PC clearly visible, score 2: PC visible, score 3: PC visible as cracks in the $\mathrm{VF}$, score 4: PC visible through the VF, score 5: PC not visible (Fig. 1(b)). VF on the heart surface was scored according to a scale from 0 to 2 , where score 0 : no VF, score 1 : VF on the heart surface, and score 2: severe accumulation of VF on the heart surface. The fish length, sex, body weight before and after evisceration, and weights of livers and hearts were recorded. The fish were filleted by hand, and the weight of right and left fillet was recorded.

\section{Serum analyses}

Blood was collected aseptically from the caudal vein in vacutainers containing clot activator $\mathrm{SiO}_{2}$ and centrifuged at $850 \mathrm{~g}$ for $10 \mathrm{~min}$ at $4^{\circ} \mathrm{C}$. The serum was transferred to separate tubes and frozen at $-25^{\circ} \mathrm{C}$ until analysed spectrophotometrically at Norwegian University of Life Sciences, Oslo Central Laboratory (ADVIA ${ }^{\circledR} 1800$, Siemens Healthcare Diagnostics Inc.) according to Tietz $^{(29)}$.

\section{RNA isolation and reverse transcription}

Liver, spleen and skeletal muscle were stored in RNAlater (Ambion) before RNA was isolated using an Agencourt $^{\circledR}$ RNAdvance $^{\mathrm{TM}}$ Tissue Total RNA Purification Kit (Beckman Coulter Inc.) according to the manufacturer's protocol. NanoDrop 1000 Spectrophotometer (ThermoFisher Scientific) was used to evaluate the RNA quality and quantity. The quality of the RNA was further assessed with an Agilent ${ }^{\circledR} 2100$ Bioanalyzer ${ }^{\mathrm{TM}}$ RNA 6000 Nano kit (Agilent Technology Inc.). All RNA samples had RNA Integrity Number value higher than 8.

cDNA was synthesised from $1000 \mathrm{ng}$ total RNA in a $20 \mu \mathrm{l}$ reaction volume using TaqMan Reverse Transcription Reagents (Applied Biosystems, ThermoFisher) with random hexamers as reaction primers. The thermocycling conditions included incubation at $25^{\circ} \mathrm{C}$ for $10 \mathrm{~min}$ followed by $37^{\circ} \mathrm{C}$ for $30 \mathrm{~min}$ and $95^{\circ} \mathrm{C}$ for $5 \mathrm{~min}$.

\section{Microarray}

Analyses were performed with Nofima's 44k DNA oligonucleotide microarray Salgeno containing probes to all protein coding genes of Atlantic salmon. Analyses included liver and skeletal muscle (pooled per sea cage). RNA was extracted with a (a)

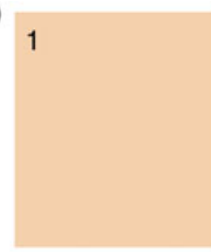

(b)

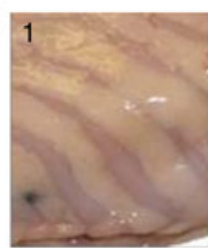

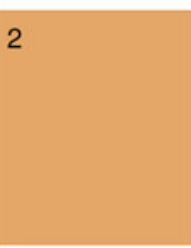
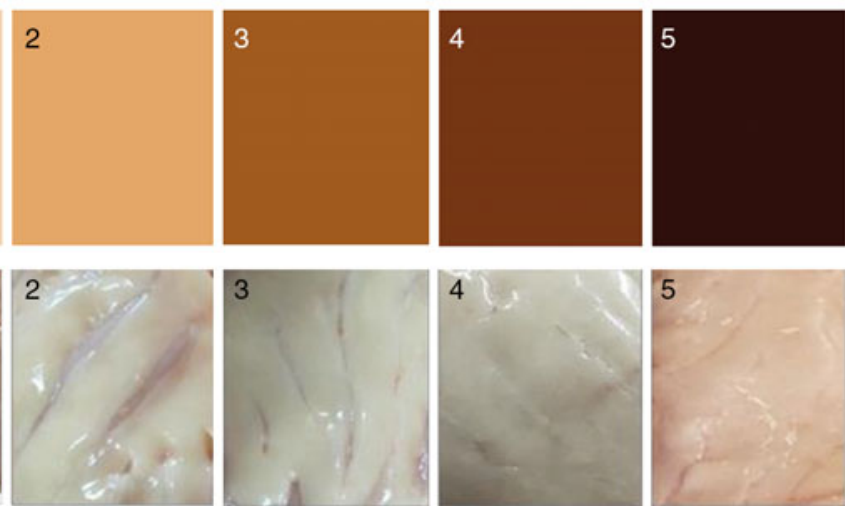

Fig. 1. Scale for assessment of visual liver colour (a) and visceral fat according to visibility of pyloric caeca (b) of Atlantic salmon 
PureLink RNA Mini Kit (Thermo Fisher Scientific). Microarrays were manufactured by Agilent Technologies; the reagents and equipment were purchased from the same provider. RNA amplification and labelling were performed with a One-Color Quick Amp Labelling Kit, and a Gene Expression Hybridization kit was used for fragmentation of labelled RNA. Total RNA input for each reaction was $500 \mathrm{ng}$. After overnight hybridisation in an oven $\left(17 \mathrm{~h}, 65^{\circ} \mathrm{C}\right)$, arrays were washed with Gene Expression Wash Buffers 1 and 2 and scanned with an Agilent scanner. Subsequent data analyses were performed with Nofima's bioinformatics pipeline STARS ${ }^{(30)}$. Differentially expressed genes were selected by expression ratio $>1 \cdot 5$-fold and $P<0.05$.

\section{Histopathology}

The following tissues were sampled for histopathological examination: liver (centre), heart (apex), thyroid gland, skin and skeletal muscle (below the dorsal fin, at the lateral line) and hindgut. Tissues were fixed in formalin ( $4 \%$ formalin, $0 \cdot 08 \mathrm{~m}$ sodium phosphate, $\mathrm{pH} 7 \cdot 0$ ), processed in a Thermo Scientific Excelsior ${ }^{\circledR}$ tissue processor and embedded in paraffin Histowax using a Tissue - Tek ${ }^{\circledR}$, TEC 5 (Sakura) embedding centre. Embedded tissue was sectioned at $1 \cdot 5-2 \mu \mathrm{m}$ using a Leica RM 2255. Microtome sections were mounted on glass slides and stained with haematoxylin-eosin. In addition, gut samples were stained with periodic acid Schiff for mucus and von Kossa's silver nitrate for Ca. Stained slides were scanned in an Aperio Scan Scope AT Turbo slice scanner and read using Aperio Image Scope (Leica). Slides were examined and scored 'blind', that is, without information about the background of the fish. Tissues were examined for pathological lesions and scored on a scale from 0 to 3 where score 0 : no pathological changes; score 1: mild changes; score 2: moderate pathological changes; score 3: severe pathological changes.

\section{Meat quality analyses}

The fish were filleted immediately after slaughtering in the pre-rigour state. The fillets were packed individually in sealed plastic bags and stored on ice for 1 week before analysing. Fillet quality analyses included suitability for processing, analysed as degree of fillet gaping (score 0-5) after simulating commercial processing conditions (FHF Industry standard) ${ }^{(31)}$, fillet firmness (instrumentally using a TA-XT2, Stable Micro Systems Ltd and flat-ended $12.5 \mathrm{~mm}$ probe at $1 \mathrm{~mm} / \mathrm{s}$ compression speed) ${ }^{(32)}$, fillet colour (visual assessment, SalmoFan colour score, DSM under standardised light conditions in a Salmon Colour Box, Skretting) and number of melanised muscle segments (myomers). Firmness and colour were analysed above the lateral line just below the cranial part of the dorsal fin and between the caudal part of the dorsal fin and the gut (i.e. Norwegian Quality Cut, $\mathrm{NQC}^{(33)}$ ). The NQC was used for analysing content of protein, fat and astaxanthin, FA composition and collagen characteristics.

\section{Chemical analyses of fillets and liver}

Tissue from forty fish from each dietary group was used for chemical analyses (ten from each sea cage). Protein (Nx6.25
Kjeldahl; NMKL 6) and total astaxanthin content including ester forms were analysed in skeletal muscle (NQC cutlet) (LC-DAD, DSM version 1.5 2009). Total lipids were extracted from fillets (NQC) and liver according to the method described by Folch et $a l .{ }^{(34)}$, and FA composition was analysed in the chloroform-methanol phase according to the method described by Mason et al. ${ }^{(35)}$. In brief, the extracts were dried under $\mathrm{N}_{2}$ gas and the residual lipid extract was trans-methylated overnight with $2^{\prime}, 2^{\prime}$-dimethoxypropane, methanolic- $\mathrm{HCl}$ and benzene at room temperature. The methyl esters formed were separated in a gas chromatograph (Hewlett Packard 6890; HP) with a split injector, using a SGE BPX70 capillary column (length $60 \mathrm{~m}$; internal diameter $0.25 \mathrm{~mm}$ and film thickness $0.25 \mu \mathrm{m}$; SGE Analytical Science) flame ionisation detector and HP Chem Station software. The results were analysed using the HP Chem Station software (Hewlett Packard 6890; HP). The carrier gas was He, and injector and detector temperatures were set at $270^{\circ} \mathrm{C}$. The oven temperature was raised from 50 to $180^{\circ} \mathrm{C}\left(10^{\circ} \mathrm{C} / \mathrm{min}\right)$ and then increased to $240^{\circ} \mathrm{C}\left(0 \cdot 7^{\circ} \mathrm{C} / \mathrm{min}\right)$. The relative amount of each FA was expressed as a percentage of the total amount of FA in the analysed sample.

FA composition of different lipid classes in fillets and feeds was analysed according to Bou et al. ${ }^{(36)}$. In brief, NEFA, PL, mono- and diacylglycerols and TAG were separated by TLC using a mixture of petroleum ether, diethyl ether and acetic acid (113:20:2, by vol.) as the mobile phase. The hexane phase was applied onto the TLC plate and dried. The plates were kept in the mixture solution until the liquid reached $1 \mathrm{~cm}$ from the upper edge of the plates. The lipids were visualised by dipping the plates in copper sulphate solution. The spots corresponding to NEFA, PL, mono- and diacylglycerols and TAG were identified by comparison with known standards by a Bioscan AR-2000 Radio-TLC \& Imaging Scanner and quantified with the WinScan Application version 3.12 (Bioscan Inc.). Lipids were separated on silica gel plates impregnated with silver nitrate ( $4 \%$ silver nitrate in methanol-water 9:1, v/v) in toluene-ethyl acetate $(90: 10, v / v)$, and specific FA were identified by comparison with known standards by a Bioscan AR-2000 Radio-TLC \& Imaging Scanner (Bioscan Inc.).

\section{Connective tissue and collagen determinations}

Isolation of connective tissue was determined according to Borderías \& Montero ${ }^{(37)}$. Total amino acid analyses of the isolated connective tissue were performed by HPLC using norleucine as an internal standard (Sigma-Aldrich, Inc.) as described by Moreno et al. ${ }^{(38)}$. Fourier transform IR spectroscopy analyses were performed by recording IR spectra between 4000 and 650/ cm using an IR spectrometer (Spectrum 400, Perkin-Elmer Inc.) equipped with an ATR prism crystal accessory (spectral resolution $4 / \mathrm{cm}$ ). The microstructure of the collagen fibrils was determined after a consecutive drying process in increased ethanol concentrations (from 30 to $100 \%$ ethanol) and then analysed using a scanning electron microscopy QUANTA 200 (FEI Company). This was operated with low vacuum to allow high-resolution inspection and support the analysis of non-conductive hydrated samples in their original condition with the large-field detector, as it is close to the sample and will prevent 
loss of electrons. Low vacuum resolution conditions for secondary electrons were $3.0 \mathrm{~nm}$ at $30 \mathrm{kV}$ and $<12 \mathrm{~nm}$ at $3 \mathrm{kV}$. The accelerating voltage was $23 \mathrm{kV}$, the low vacuum was 0.50 torr and the working distance was $10 \mathrm{~mm}$. Images of $50 \mu \mathrm{m}$ were recorded.

\section{Calculations}

The feed conversion ratio $(\mathrm{FCR})=(\mathrm{kg}$ feed fed $)$

$$
\times(\mathrm{kg} \text { final biomass }-\mathrm{kg} \text { initial biomass })^{-1} \text {. }
$$

Thermal growth coefficient $($ TGC $)=\left(\mathrm{W}_{1}^{1 / 3}-\mathrm{W}_{0}^{1 / 3}\right) \times 1000 / \mathrm{d}^{\circ}$.

where $W_{0}$ is the start weight $(\mathrm{g}), W_{1}$ is the final weight $(\mathrm{g}), t$ is the number of days and $d^{\circ}$ is the sum of day degrees.

$$
\begin{aligned}
\text { Condition factor }(\mathrm{CF}) & : \text { (body weight }(\mathrm{g})) \\
& \times(\text { fish fork length }(\mathrm{cm}))^{-3} \times 100 .
\end{aligned}
$$

Slaughter yield: (gutted body weight)

$$
\times(\text { whole body weight })^{-1} \times 100 \text {. }
$$

Fillet yield: (Fillet weight $) \times(\text { whole body weight })^{-1} \times 100$

Hepatosomatic index (HSI): (liver weight)

$$
\times(\text { whole fish weight })^{-1} \times 100 \text {. }
$$

Cardio somatic index (CSI): (heart weight)

$$
\times(\text { whole fish weight })^{-1} \times 100
$$

\section{Statistical analyses}

Normality and homogeneity of variance were confirmed, and percentage data were arcsine-transformed before analyses. Nonparametric traits were analysed by Kruskal-Wallis test. Otherwise, the dietary treatments were compared by unpaired $t$ test (SAS, version 9.4 for Windows, SAS Institute Inc.). The number of individuals used for fillet quality analyses was based on effect size evaluation on fillet texture measurements by Sigurgisladottir et al. ${ }^{(39)}$, based on the method by Nortvedt ${ }^{(40)}$. Sex was not included in the statistical model as the number of males and females was similar for the dietary groups (FM $44 \%$ females and $56 \%$ males; KM $46 \%$ females and $54 \%$ males; $P=0.76$ ). The significant difference in the transcript level of the target marker genes between the control and the FM and KM groups was determined by Student's $t$ test for independent samples; the threshold of differential expression in microarray analyses was $1 \cdot 5$-fold. All data are expressed as mean values with their standard errors unless noted otherwise. The level of significance was set at $5 \%(P<0 \cdot 05)$.

\section{Results}

\section{Production efficiency and biometric traits}

The body weight increased from 2.3 to $3.9 \mathrm{~kg}$ during the feeding period. The males were $8.8 \%$ heavier than the

\begin{tabular}{|c|c|c|c|c|c|}
\hline & \multicolumn{2}{|c|}{ FM } & \multicolumn{2}{|c|}{$\mathrm{KM}$} & \multirow[b]{2}{*}{$P$} \\
\hline & Mean & SE & Mean & SE & \\
\hline Body weight (g) & 3833 & 37 & 3923 & 43 & 0.08 \\
\hline TGC & 3.88 & 0.03 & 3.92 & 0.13 & 0.41 \\
\hline FCR & 1.06 & 0.02 & 1.07 & 0.03 & 0.36 \\
\hline Mortality (\%) & 1.0 & 0.4 & 1.3 & 0.6 & 0.72 \\
\hline \multicolumn{6}{|l|}{ Biometric traits } \\
\hline Condition factor & 1.41 & 0.01 & 1.44 & 0.01 & 0.05 \\
\hline Slaughter yield (\%) & $87 \cdot 8$ & 0.3 & 88.0 & 0.7 & 0.51 \\
\hline Fillet yield (\%) & $66 \cdot 3$ & 0.3 & 66.9 & 0.2 & 0.06 \\
\hline Hepatosomatic index (\%) & $1 \cdot 11$ & 0.02 & $1 \cdot 12$ & 0.01 & 0.50 \\
\hline Cardio somatic index (\%) & 0.14 & 0.003 & 0.13 & 0.003 & 0.77 \\
\hline \multicolumn{6}{|l|}{ Visual scoring } \\
\hline Wounds & 0.4 & 0.1 & 0.3 & 0.1 & 0.88 \\
\hline Eye lens opacity & 0.19 & 0.11 & 0.03 & 0.02 & 0.09 \\
\hline Visceral fat & $3 \cdot 4$ & 0.1 & 3.4 & 0.1 & 0.68 \\
\hline Fat on heart surface & 0.7 & 0.1 & 0.4 & 0.1 & 0.03 \\
\hline Liver darkness & 2.9 & 0.1 & $3 \cdot 7$ & 0.1 & $<0.0001$ \\
\hline $\begin{array}{l}\text { Number of dark stained } \\
\text { myomera }\end{array}$ & 0.9 & $0 \cdot 2$ & 0.5 & 0.2 & 0.13 \\
\hline
\end{tabular}

Table 5. Growth, feed conversion ratio, biometric traits and visual scoring of external and internal traits of Atlantic salmon fed a low fishmeal diet (FM group), or the same diet with fishmeal partly substituted by krill meal (KM group), during the finishing feeding period of $90 \mathrm{~d}$ before harvesting ${ }^{*}$ (Mean values with their standard errors)

TGC, thermal growth coefficient; FCR, feed conversion ratio.

* Results on body weight, TGC, FCR and mortality are based on registrations of all fish in each of the four sea cages per diet (100 fish per cage initially). For the other traits, $n$ 20 randomly selected fish per sea cage ( $n 80$ per diet).

females ( $4.1 v .3 .7 \mathrm{~kg} ; P<0 \cdot 0001)$, but diets had no effect on final weight, TGC, feed conversion ratio or biometric traits, except for the body shape that was more voluminous of the KM group (higher CF) (Table 5).

\section{Welfare indicators and organ appearance}

While the KM group tended to have lower scores for eye lens opacity $(P=0.09)$, the occurrence of wounds was low and similar for both dietary groups. Accumulation of fat on the hearts was higher in the FM group, and livers were paler compared with the KM group. The score for VF was similar for the FM and KM groups (Table 5).

\section{Serum analyses}

None of the parameters analysed in serum differed significantly between the dietary groups (Table 6). There was an overall negative correlation between serum alanine aminotransferase (ALT) and the visual fat accumulation in the viscera $(r-0.85$; $P=0.0007)$ and on the heart surface $(-0.71 ; P=0.05)$, while colour, relative size and histopathological changes of the liver showed no significant correlation with the ALT.

\section{Histopathology}

There were no significant differences between the FM and KM groups for any of the histopathological parameters investigated (Table 6). There were no histopathological lesions in skin or spleen. Both groups showed mild lesions in heart and liver, with sparse focal proliferation of epi- and/or endocardium in heart and sparse peribiliar and perivascular inflammatory cell infiltration in liver. One individual in the FM group showed sparse 
Table 6. Serum chemistry and histopathology of Atlantic salmon fed a lowfishmeal diet (FM group), or the same diet with fishmeal partly substituted by krill meal (KM group)

(Mean values with their standard errors; $n 4$ sea cages/diet, five fish per sea cage)

\begin{tabular}{|c|c|c|c|c|c|}
\hline & \multicolumn{2}{|c|}{ FM } & \multicolumn{2}{|c|}{ KM } & \multirow[b]{2}{*}{$P$} \\
\hline & Mean & SE & Mean & SE & \\
\hline \multicolumn{6}{|l|}{ Serum chemistry } \\
\hline $\mathrm{Na}(\mathrm{mmol} / \mathrm{l})$ & $159 \cdot 3$ & $1 \cdot 1$ & 160 & $1 \cdot 3$ & 0.84 \\
\hline Chloride (mmol/l) & $131 \cdot 2$ & 1.4 & $132 \cdot 5$ & 1.4 & 0.86 \\
\hline $\mathrm{Ca}(\mathrm{mmol} / \mathrm{l})$ & $3 \cdot 2$ & 0.03 & $3 \cdot 1$ & 0.12 & 0.90 \\
\hline $\mathrm{K}(\mathrm{mmol} / \mathrm{l})$ & 0.6 & 0.02 & 0.8 & $0 \cdot 16$ & 0.44 \\
\hline Total protein $(\mathrm{g} / \mathrm{l})$ & $49 \cdot 3$ & 1.4 & 48.5 & $2 \cdot 2$ & 0.70 \\
\hline Glucose $(\mathrm{mmol} / \mathrm{l})$ & $5 \cdot 0$ & 0.03 & $5 \cdot 3$ & 0.31 & $0 \cdot 10$ \\
\hline Creatinine $(\mu \mathrm{mol} / \mathrm{l})$ & $15 \cdot 7$ & 0.5 & $15 \cdot 5$ & 0.9 & 0.81 \\
\hline Alanine aminotransferase (U/I) & 12.5 & 3.5 & $13 \cdot 3$ & 2.5 & 0.74 \\
\hline \multicolumn{6}{|l|}{ Histopathological scores $(0-3)^{\star}$} \\
\hline Heart & 0.5 & 0.1 & 0.5 & 0.1 & 0.76 \\
\hline Spleen & 0.0 & 0.0 & 0.0 & 0.0 & - \\
\hline Liver & 0.1 & $0 \cdot 1$ & 0.4 & $0 \cdot 1$ & 0.07 \\
\hline Skeletal muscle & 0.1 & $0 \cdot 1$ & 0.0 & 0.0 & 0.32 \\
\hline Skin & 0.0 & 0.0 & 0.0 & 0.0 & - \\
\hline Thyroidea & $1 \cdot 8$ & $0 \cdot 1$ & 1.8 & 0.1 & 0.68 \\
\hline Hindgut & 0.7 & 0.2 & 0.7 & 0.2 & 0.78 \\
\hline
\end{tabular}

* Score 0: no pathological changes; score 1: mild changes; score 2: moderate pathological changes; score 3 : severe pathological changes.

degeneration/necrosis of white skeletal muscle. Both groups showed thyroid lesions, comprising empty follicles with irregular shape and varying epithelial height. Several individuals in both groups had inflammation in the lamina propria/submucosa of the hindgut. The overall pathological score of the thyroidea and hindgut was similar for the FM and KM groups. However, periodic acid Schiff staining showed the presence of ectopic epithelial cells containing mucus in lamina propria in the hindgut only in salmon belonging to the FM group, and von Kossa staining revealed focal $\mathrm{Ca}$ deposits in $20 \%$ of the fish belonging to the FM group, but none of the KM group. Micrographs illustrating examples from the histological examination are shown in Fig. 2.

\section{Microarray}

Analyses of livers showed seventy-three differentially expressed genes whereof forty-four genes had higher expression levels in the KM group (Table 7). Sixteen genes are known or expected to have immune roles, whereof seven and nine immune genes showed, respectively, lower and higher expression in the KM group. Three genes encoding a lectin (ladderlectin) were up-regulated in the KM group. Moreover, krill supplementation increased expression of three genes encoding tight junction proteins (connexin and two cadherins).

Analyses of skeletal muscle showed 123 DEG whereof 108 genes had higher expression levels in the KM group (Table 8). The largest functional group that responded to feeds was genes for myofiber protein where eleven genes had higher expression in the KM group (seven of them encode different forms of myosin heavy chain) and only one gene with lower expression. Apart from mitochondria (six genes), dietary effects on expression of genes involved a $1 \cdot 7$-fold increased expression of MTP (Microsomal TAG transfer protein large subunit minor). The expression differences of immune genes were minor in muscle.

\section{Fillet quality}

The KM group had fewer slits between the muscle segments (myomers) in fillets subsequent to handling, and visual fillet colour was significantly redder compared with the FM group. Instrumental analyses revealed that fillets of the KM group were firmer compared with the FM group. Results on fillet gaping, colour and firmness are presented in Fig. 3, where fillet colour

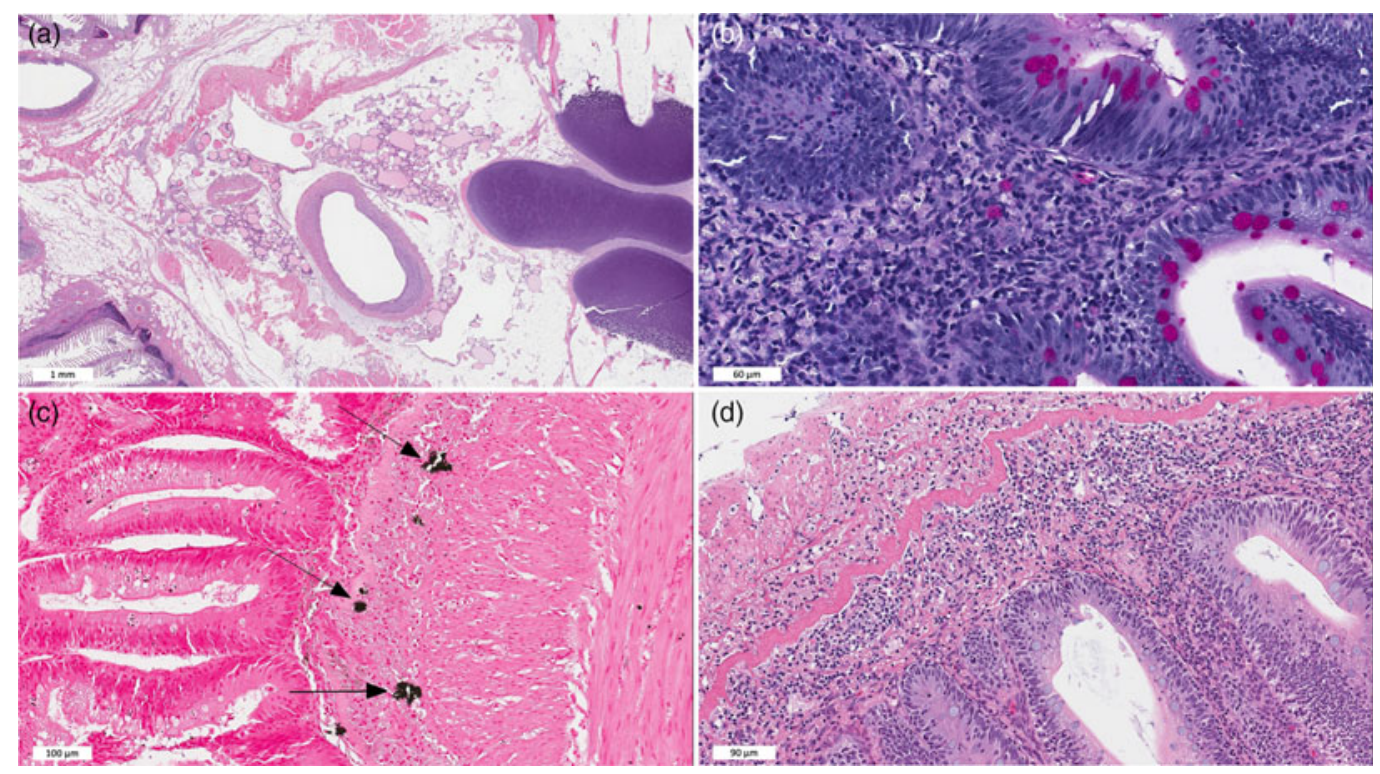

Fig. 2. Light micrograph images of (a) thyroid tissue (haematoxylin-eosin (HE) stained), overview; (b) hindgut (periodic acid Schiff stained), mucus stained purple; (c) hindgut (von Kossa stained), focal dystrophic calcinosis; (d) hindgut (HE stained), cell infiltration in lamina propria and submucosa. 
Table 7. Differentially expressed genes (folds), as determined by microarray analyses, in liver of Atlantic salmon fed a low fishmeal diet (FM group), or the same diet with fishmeal partly substituted by krill meal (KM group)* (Mean values)

\begin{tabular}{ll}
\hline Gene & $\mathrm{KM} \mathrm{v.} \mathrm{FM}$ \\
\hline Macrophage colony-stimulating factor 1 & $2 \cdot 0$ \\
Liver-expressed antimicrobial peptide 2 & 1.7 \\
Suppressor of cytokine signalling 2 (two genes) & $1.5-1.6$ \\
Ladderlectin-like (three genes) & $1.5-1.8$ \\
Suppressor of cytokine signalling 3b & $-1 \cdot 7$ \\
CD4-like (two genes) & $-1 \cdot 7-2 \cdot 0$ \\
Toll-like receptor 5 & $-2 \cdot 2$ \\
C-C motif chemokine 13 (two genes) & $-1.7-2 \cdot 2$ \\
Complement C1q TNF-related protein & -2.5 \\
C1q and TNF-like domains & -2.5 \\
Complement component 1q3a & -3.6 \\
Cadherin-13-like & 2.4 \\
Connexin 43.4 & 1.6 \\
Cadherin 2, neuronal & 1.6 \\
\hline
\end{tabular}

${ }^{*}$ Results are shown as the difference between the KM $v$. FM groups for selected genes where $P<0.05$ between the dietary groups.

Table 8. Differentially expressed genes (folds), as determined by microarray analyses, in skeletal muscle of Atlantic salmon fed a low fishmeal diet (FM group), or the same feed with fishmeal partly substituted by krill meal (KM group)*

(Mean values)

\begin{tabular}{lc}
\hline Gene & $\mathrm{KM} v . \mathrm{FM}$ \\
\hline Suppressor of cytokine signalling & -1.5 \\
Chromosome maintenance (four genes) & $1.6-1.9$ \\
Signalling (eight genes) & $1.5-1.7$ \\
Cell cycle (two genes) & $1.5-1.7$ \\
Transcription (three genes) & $1.7-2.2$ \\
Proteasome (two genes) & $1.6-2.1$ \\
Lysosomes (two cathepsins) & $1.7-2.1$ \\
Myofiber proteins (twelve genes) & $1.5-2.3$ \\
Differentiation (four genes) & $1.6-2.1$ \\
Growth factor (three genes) & $1.6-1.8$ \\
Mitochondria (six genes) & $1.6-1.7$ \\
Metabolism lipids (two genes) & $1.6-1.7$ \\
Metabolism ion (three genes) & $1.5-1.8$
\end{tabular}

* Results are shown as difference between the KM $v$. FM groups for selected genes where $P<0.05$ between the dietary groups.

and firmness are given as the average of analyses of the anterior and posterior part of the fillet. Fillet colour was less intense in the anterior part (FM: 24.7 ( $\mathrm{SE} 0 \cdot 1$ ) and KM 25.2 (sE $0 \cdot 1) ; P=0.0002)$ compared with the posterior part (NQC) (FM: 25.9 (sE 0.2) and KM: 26.3 (sE 0.1); $P=0 \cdot 11$ ). The astaxanthin level analysed in the NQC was numerically higher in the KM group $(7.2$ (sE 0.2$) \mathrm{mg} / \mathrm{kg}$ ) compared with the FM group (6.6 (SE 0.3$) \mathrm{mg} / \mathrm{kg})$, but the difference was not statistically significant $(P=0.09)$. Furthermore, the astaxanthin concentration correlated negatively with liver fat content $(r-0.94$; $P=0.005)$. The firmness of the FM group was similar for the anterior and posterior fillet part (8.3 (sE 0.2)), while the fillets of the KM group were firmer in the anterior than the posterior region $(9.2(\operatorname{se~} 0.3) \mathrm{N} v .8 .5$ (se 0.4$) ; P=0.002)$.

Dietary treatment had no significant effect on the average number of dark hyperpigmented myomers (Table 5), protein content (FM 22.1 (SE 0.4) and KM 21.8 (SE 0.3); $P=0.61$ ) or fat content (FM 21.5 (se 1.3) and KM 21.2 (sE 0.6); $P=0.94$ ). The
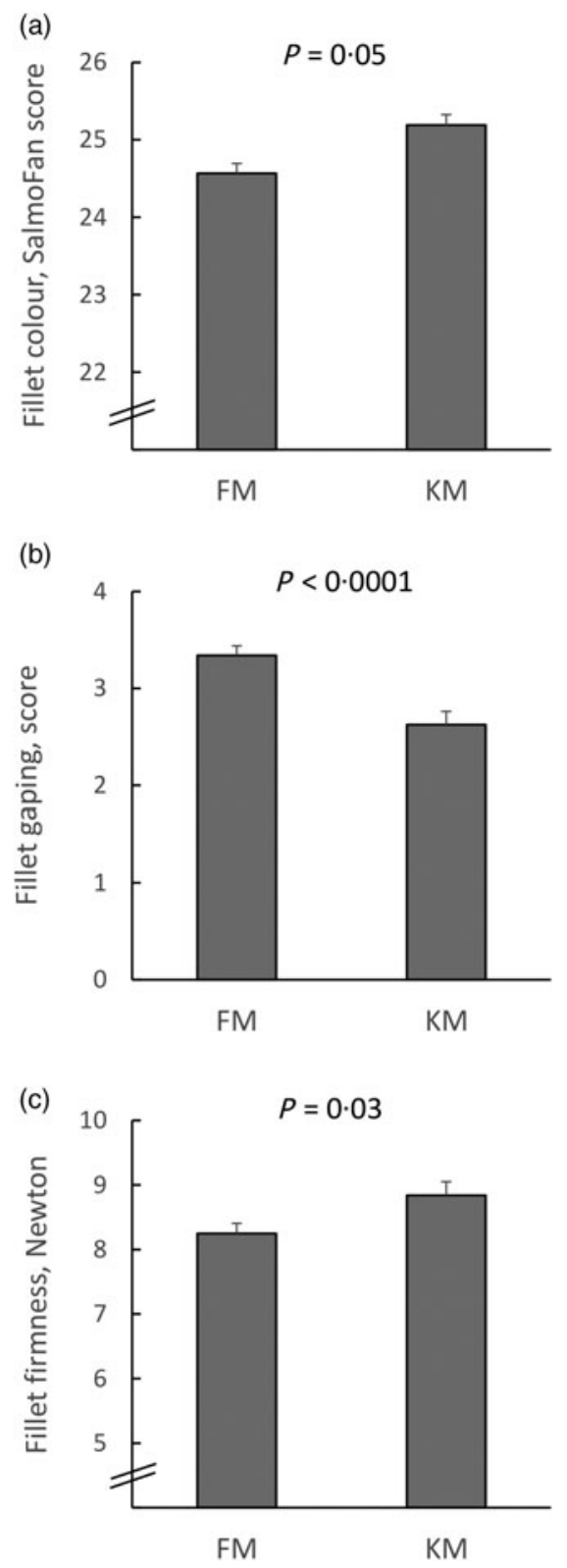

Fig. 3. Fillet colour intensity (SalmoFan $\left.{ }^{\mathrm{TM}}\right)(\mathrm{a})$, degree of fillet gaping (b) and fillet firmness (c) of Atlantic salmon fed a diet with $15 \%$ fishmeal (FM group), or the same diet with fishmeal partly substituted by krill meal (KM group) during the finishing feeding period of $90 \mathrm{~d}$ before harvesting ( $n 80$ per diet group; $n 20$ per sea cage).

fat content in livers was 7.5 (SE 0.2 ) $\%$ and 8.6 (SE 0.5 ) \% for the KM and FM group, respectively $(P=0 \cdot 18)$.

\section{Fatty acid composition of fillets}

Salmon fed the KM diet had higher relative content (percentage of total FA) of C18 : 1, C18:2n-6 and C20 $5 n-3$ (EPA) and lower relative content of $\mathrm{C} 20: 1, \mathrm{C} 22: 1$ and $\mathrm{C} 22: 6 n-3$ (DHA) compared with the salmon fed the FM diet. The sum of EPA and DHA did not differ significantly between the feed groups. The total content of $n$-1 was lower (mainly due to lower content of $20: 1 n-9$ and $22: 1 n-11$ ), while the sum of $n-6$ FA was higher of the KM group compared with the FM group (Table 2). 
Table 9. Relative fatty acid composition (\% of total fatty acids) of TAG, mono- and diacylglycerols (MAG), phospholipids (PL) and NEFA of skeletal muscle of Atlantic salmon fed a low fishmeal diet (FM group), or the same diet with fishmeal partly substituted by krill meal (KM group) (Mean values with their standard errors)

\begin{tabular}{|c|c|c|c|c|c|c|c|c|c|c|c|c|c|c|c|c|}
\hline & \multicolumn{4}{|c|}{ TAG } & \multicolumn{4}{|c|}{ MAG } & \multicolumn{4}{|c|}{ PL } & \multicolumn{4}{|c|}{ NEFA } \\
\hline & \multicolumn{2}{|c|}{$\mathrm{FM}$} & \multicolumn{2}{|c|}{$\mathrm{KM}$} & \multicolumn{2}{|c|}{ FM } & \multicolumn{2}{|c|}{$\mathrm{KM}$} & \multicolumn{2}{|c|}{ FM } & \multicolumn{2}{|c|}{$\mathrm{KM}$} & \multicolumn{2}{|c|}{$\mathrm{FM}$} & \multicolumn{2}{|c|}{$\mathrm{KM}$} \\
\hline & Mean & SE & Mean & SE & Mean & SE & Mean & SE & Mean & SE & Mean & SE & Mean & SE & Mean & SE \\
\hline Total & 93.8 & 0.3 & 93.5 & 0.6 & 1.3 & 0.4 & $1 \cdot 3$ & 0.2 & $2 \cdot 8$ & 0.2 & $2 \cdot 7$ & 0.3 & $2 \cdot 1$ & 0.2 & 2.5 & 0.2 \\
\hline $14: 0$ & 2.4 & 0.01 & $2 \cdot 5^{\star \star}$ & 0.01 & 1.6 & 0.08 & 1.5 & 0.15 & 1.0 & 0.28 & 1.2 & 0.09 & 3.1 & 0.15 & $2 \cdot 8$ & 0.11 \\
\hline $16: 0$ & 9.5 & 0.03 & $9 \cdot 7^{\star \star}$ & 0.04 & 6.0 & 0.29 & $6 \cdot 0$ & 0.62 & $14 \cdot 8$ & 0.56 & $16 \cdot 1$ & 1.08 & $16 \cdot 1$ & 0.95 & $13 \cdot 7^{*}$ & 0.39 \\
\hline $18: 0$ & 2.4 & 0.01 & 2.5 & 0.03 & $2 \cdot 3$ & 0.60 & $3 \cdot 1$ & 0.83 & 2.7 & 0.22 & 2.9 & 0.22 & $2 \cdot 7$ & 0.14 & $2 \cdot 3$ & 0.10 \\
\hline $20: 0$ & 0.4 & 0.00 & 0.4 & 0.00 & $1 \cdot 2$ & 0.55 & $1 \cdot 16$ & 0.37 & 0.14 & 0.01 & $0.05^{\star}$ & 0.02 & 0.3 & 0.08 & 0.2 & 0.01 \\
\hline $18: 3 n-3$ & $5 \cdot 0$ & 0.03 & 4.9 & 0.11 & 4.9 & 0.61 & $5 \cdot 6$ & 0.55 & 3.8 & 0.01 & 3.9 & 0.28 & 4.6 & 0.62 & $6 \cdot 3$ & 0.38 \\
\hline $20: 5 n-3$ & 1.8 & 0.02 & 1.9 & 0.01 & 3.0 & 0.29 & 3.5 & 0.38 & $7 \cdot 2$ & 0.18 & 7.4 & 0.49 & 3.2 & 0.42 & $4 \cdot 7^{\star}$ & 0.32 \\
\hline $22: 5 n-3$ & 0.8 & 0.00 & 0.8 & 0.01 & $1 \cdot 3$ & 0.21 & $1 \cdot 3$ & $0 \cdot 10$ & $2 \cdot 6$ & 0.06 & $2 \cdot 3$ & 0.15 & 0.8 & 0.12 & 1.0 & 0.02 \\
\hline $22: 6 n-3$ & 2.8 & 0.01 & $2 \cdot 6^{\star \star \star}$ & 0.02 & $5 \cdot 1$ & $1 \cdot 17$ & $5 \cdot 3$ & $1 \cdot 28$ & 24.5 & 0.62 & $22 \cdot 2$ & 1.56 & 2.6 & 0.52 & 3.8 & 0.38 \\
\hline $18: 2 n-6$ & $13 \cdot 4$ & 0.07 & $13 \cdot 6^{\star}$ & 0.05 & $11 \cdot 3$ & $2 \cdot 31$ & $11 \cdot 2$ & $2 \cdot 16$ & $7 \cdot 2$ & 0.07 & $6 \cdot 8$ & 0.34 & $12 \cdot 4$ & $1 \cdot 23$ & $15 \cdot 3$ & 0.60 \\
\hline $20: 2 n-6$ & $1 \cdot 1$ & 0.02 & $1 \cdot 1$ & 0.01 & 0.6 & 0.13 & 0.5 & 0.16 & 0.7 & 0.01 & 0.7 & 0.07 & 0.8 & 0.09 & $1 \cdot 1^{*}$ & 0.03 \\
\hline $20: 4 n-6$ & 0.29 & 0.00 & 0.29 & 0.00 & 0.58 & 0.46 & $1 \cdot 12$ & 0.49 & 0.58 & 0.13 & 0.66 & 0.13 & 0.28 & 0.04 & 0.32 & 0.01 \\
\hline $18: 1 n-7$ & 1.2 & 0.06 & 1.3 & 0.08 & $2 \cdot 0$ & 0.18 & 2.0 & 0.23 & 1.8 & 0.04 & 1.8 & 0.06 & 2.0 & 0.26 & $3 \cdot 0^{\star * *}$ & 0.06 \\
\hline $22: 1 n-7$ & 0.7 & 0.01 & 0.7 & 0.01 & 0.7 & 0.26 & 0.8 & 0.12 & 0.9 & 0.14 & 0.4 & 0.18 & 0.9 & 0.10 & $1 \cdot 1$ & 0.02 \\
\hline $16: 1 n-9$ & $2 \cdot 1$ & 0.01 & $2 \cdot 1$ & 0.03 & $2 \cdot 3$ & 0.35 & $2 \cdot 2$ & 0.38 & $1 \cdot 1$ & 0.06 & $1 \cdot 1$ & 0.07 & $2 \cdot 0$ & 0.39 & 1.9 & 0.24 \\
\hline $18: 1 n-9$ & 41.9 & 0.02 & $42 \cdot 8^{\star \star \star}$ & 0.1 & 31.4 & 3.53 & 29.0 & 4.04 & 17.5 & 0.24 & $16 \cdot 1$ & 0.71 & 24.8 & 1.6 & 27.9 & 0.7 \\
\hline $20: 1 n-9$ & 4.6 & 0.04 & $4 \cdot 2^{\star \star \star}$ & 0.02 & $2 \cdot 0$ & 0.55 & $2 \cdot 1$ & 0.32 & 1.3 & 0.04 & $1 \cdot 1$ & 0.08 & 2.3 & 0.23 & 2.6 & 0.08 \\
\hline $24: 1 n-9$ & 0.5 & 0.00 & $0.4^{\star * *}$ & 0.00 & 0.3 & 0.12 & 0.2 & 0.09 & 1.0 & 0.06 & $1 \cdot 1$ & 0.09 & 0.5 & 0.01 & 0.5 & 0.02 \\
\hline $18: 1 n-11$ & 0.2 & 0.03 & 0.2 & 0.02 & 0.5 & 0.24 & 0.5 & 0.17 & 0.9 & 0.20 & 1.5 & 0.20 & 3.0 & 1.82 & 0.9 & 0.36 \\
\hline $20: 1 n-11$ & 0.7 & 0.01 & 0.6 & 0.03 & 0.9 & 0.40 & 1.3 & 0.14 & 0.6 & 0.00 & 0.6 & 0.02 & 0.9 & 0.11 & 1.00 & 0.05 \\
\hline $22: 1 n-11$ & $4 \cdot 1$ & 0.03 & $3 \cdot 2^{* \star *}$ & 0.02 & 1.6 & 0.25 & 1.7 & 0.24 & 0.8 & 0.07 & 0.9 & 0.14 & $2 \cdot 4$ & 0.15 & $2 \cdot 0^{*}$ & 0.03 \\
\hline $\mathrm{EPA}+\mathrm{DHA}$ & 4.6 & 0.03 & $4 \cdot 5^{\star}$ & 0.03 & 8.06 & 1.45 & 8.7 & 1.64 & 31.6 & 0.74 & $28 \cdot 8$ & $2 \cdot 19$ & $5 \cdot 84$ & 0.93 & 8.5 & 0.70 \\
\hline Sum $n-3$ & $11 \cdot 2$ & 0.07 & $10 \cdot 8^{*}$ & 0.13 & $15 \cdot 2$ & $2 \cdot 26$ & $16 \cdot 2$ & $2 \cdot 07$ & 38.4 & 0.73 & $35 \cdot 6$ & $2 \cdot 27$ & $12 \cdot 3$ & 1.79 & $16 \cdot 4$ & $1 \cdot 18$ \\
\hline Sum $n-6$ & $15 \cdot 2$ & 0.08 & $15 \cdot 5^{\star}$ & 0.05 & 13.0 & 2.04 & 13.5 & 1.95 & 9.5 & 0.37 & 9.2 & 0.18 & $13 \cdot 8$ & 1.30 & $17 \cdot 4^{*}$ & 0.66 \\
\hline Sum $n-0$ & $15 \cdot 2$ & 0.05 & $15 \cdot 5^{\star \star}$ & 0.07 & $12 \cdot 3$ & 1.93 & 12.9 & 2.09 & $19 \cdot 8$ & 0.93 & 21.3 & 1.43 & 22.9 & 1.30 & $19 \cdot 6$ & 0.59 \\
\hline
\end{tabular}

The FA compositions of the lipid classes TAG, mono- and diacylglycerols, PL and NEFA in fillets are shown in Table 9. The FA composition of the TAG fraction reflected to a large extent the FA compositions of the diets, with higher percentages of $16: 0,18: 2 n-6$ and a tendency to higher percentage of $20: 5 n-3$ and lower percentage of $22: 6 n-3$ in fillet from the $\mathrm{KM}$ group relative to the FM group. There were no major differences in the FA compositions of the mono- and diacylglycerols and PL fractions between the two dietary groups. The NEFA fraction that is more available for metabolic conversion than the ester bond lipid fractions was to a larger extent influenced by the diet composition. $20: 4 n-3$ was reduced and its further desaturation and elongation products in the $n-3$ metabolic pathway, 20:5n-3, 22:5n-3and 22:6n-3, all increased in the KM group compared with the FM group. The same was also shown for the $n-6$ metabolic pathway, with increased percentages of the elongation and desaturation products $20: 2 n-6,20: 3 n-6$ and $20: 4 n-6$ in the KM group compared with the FM group. On the other hand, the percentages of the SFA $16: 0$ and 18:0 were lower in the KM group relative to the FM group.

\section{Connective tissue and collagen determinations}

Collagen amino acid composition extracted from salmon skeletal muscle is presented in Table 4. The composition of the collagen molecules was similar for the FM and KM groups. The most abundant amino acids were glycine followed by alanine and proline. In order to study the collagen secondary structure, second derivatives of the amide I band (Fig. 4(a)) were calculated to enhance resolution of the spectral bands and to minimise base-line variations ${ }^{(42)}$. Collagen molecules of the KM group had a lower presence of single $\alpha$-helix $(1650 / \mathrm{cm})$, random coil $(1645 / \mathrm{cm})$ and disordered structures $(1635 / \mathrm{cm})$, as well as lower intermolecular cross-links associated with $\beta$-sheets $(1695-1680 / \mathrm{cm})$. The region of carbohydrate linkage to the collagen molecules (Fig. 4(b)) corresponds to bands appearing in the range of $1775-1710 / \mathrm{cm}$.

Scanning electron microscopy analysis of purified collagen confirmed well-defined fibril morphologies (Fig. 5) which could be related to the preserved collagen structure of both collagen as indicated by the Fourier transform IR spectroscopy analysis (Fig. 4(a)). The KM group fibrils had a more compact and well-defined architecture compared with the FM group.

\section{Discussion}

The overall growth rates (TGC 3.9) and feed utilisation (feed conversion ratio 1.07) were above prognosis, as the TGC and biological feed conversion ratio of farmed Norwegian salmon average $2 \cdot 5^{(43)}$ and $1 \cdot 17^{(44)}$, respectively. Fillet fat content (21\%) was in the upper range of that generally measured in adult salmon $(14-20 \%)^{(45)}$. Fast somatic growth and high fat content are results of high energy intake that is typically seen during declining day length in autumn ${ }^{(20,46-48)}$. However, faster growth and, at the same time, lower condition factor and a strong trend towards reduced fat deposition have been seen in salmon fed 
(a)

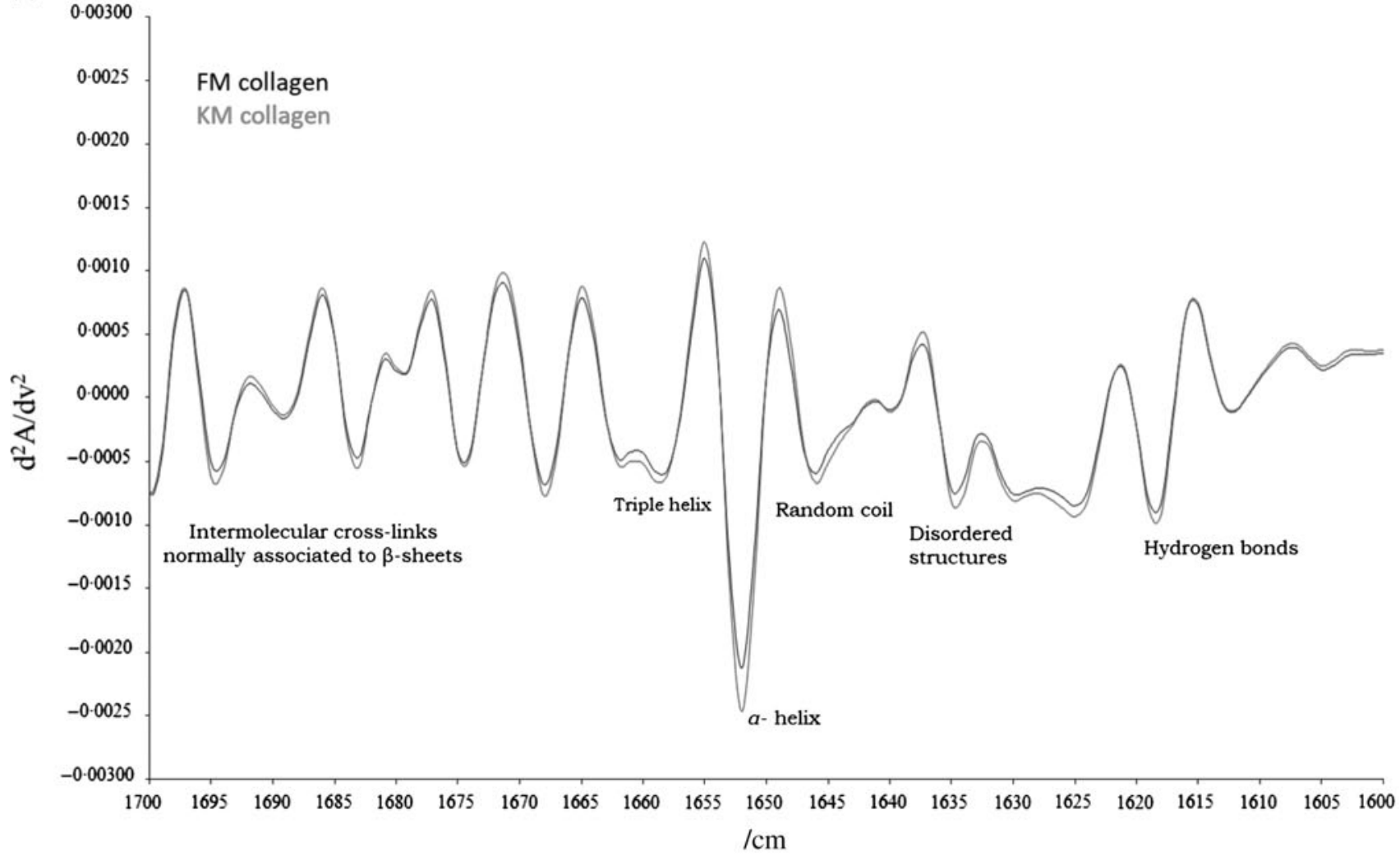

(b)

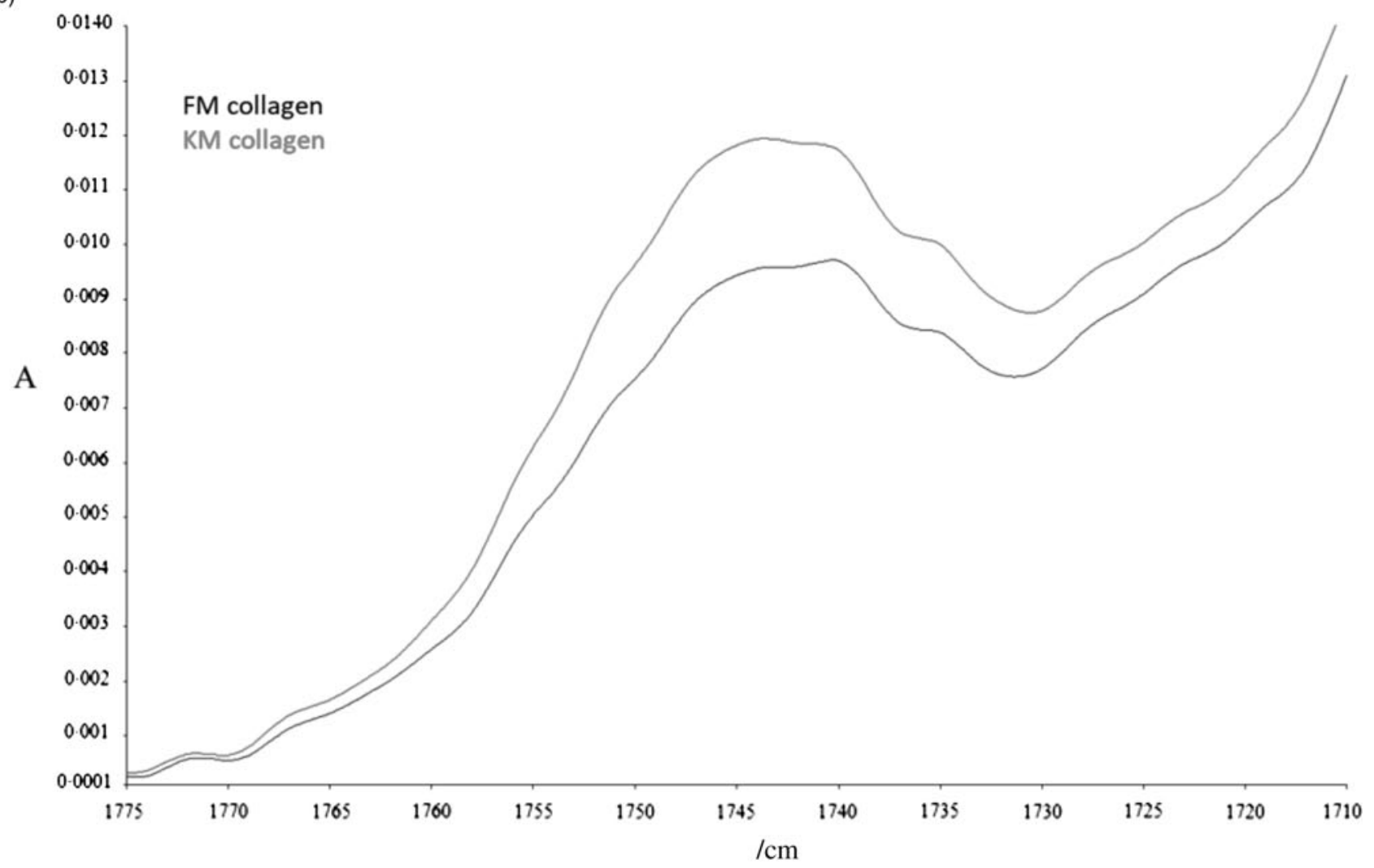

Fig. 4. Second derivate of Fourier transform IR spectroscopy (FTIR) spectra of collagen secondary structure (a) and FTIR spectra region 1775-1710/cm for collagen glycolysation (b) of collagen isolated from skeletal muscle of Atlantic salmon fed a diet with $15 \%$ fishmeal (FM group), or the same diet with fishmeal partly substituted by krill meal (KM group) during the finishing feeding period of $90 \mathrm{~d}$ before harvesting. 


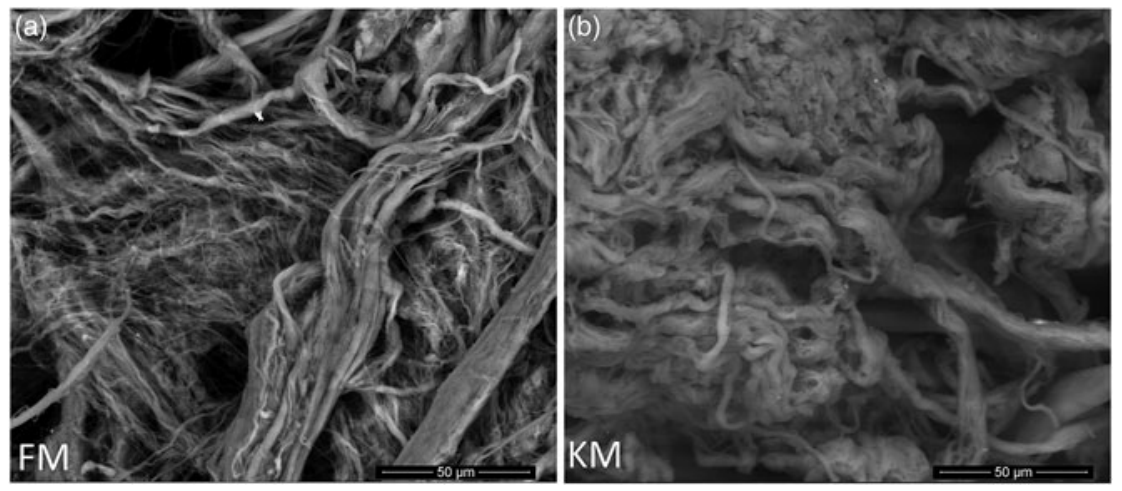

Fig. 5. Scanning electron microscope images of collagen fibrils purified from skeletal muscle of Atlantic salmon fed a diet with $15 \%$ fishmeal (FM group), or the same diet with fishmeal partly substituted by krill meal (KM group) (a) during the finishing feeding period of $90 \mathrm{~d}$ before harvesting (b).

krill meal; Hatlen et al. ${ }^{(16)}$ reported $11 \%$ higher TGC and lower $\mathrm{VF}$ in $7 \mathrm{~kg}$ salmon fed $10 \%$ dietary krill meal inclusion during 6 weeks. The lack of growth effect by dietary supplementation of krill meal in the present study may be related to the high dietary content of vegetable raw materials, unlike previous studies that used fishmeal as the major protein source. The polar pelagic environment from where the Antarctic krill is harvested is characterised by extreme seasonal changes causing considerable environmental variations and food availability ${ }^{(49)}$. Hence, variation in the effects of krill meal among studies may also be related to krill fishing season.

As the VF was similar for both fish groups, excess VF deposits did not explain the more voluminous body shape of the KM group (higher $\mathrm{CF}$ ). Rather the $0.6 \%$-units higher fillet yield $(P=0.06)$ and up-regulation of myofiber proteins indicate stimulated skeletal muscle growth. These results are in line with Hatlen et al. ${ }^{(16)}$ who suggested that krill meal may contribute to more efficient utilisation of the feed energy for protein growth (fillet production).

Serum ALT is a widely used index of liver dysfunction, although the reliability is questioned for certain species, such as chicken ${ }^{(50)}$. Krill supplementation did not alter ALT levels or any of the other serum components, as previously reported by Hansen et al. ${ }^{(51)}$. Both groups, however, had ALT values that were 1.6 times above the upper limit reported as the normal range for healthy adult salmon of $4-8 \mathrm{U} / \mathrm{l}^{(52)}$. Considering the high performance, low mortality rate and low histopathological score of both groups, reference ALT intervals for healthy salmon may need reconsideration. In humans, the presence of obesity increases the risk of elevated liver enzymes by a factor of two to three ${ }^{(53)}$. In the present study, however, an inverse correlation was observed between ALT and viscera and heart fat deposits.

The liver is involved in an array of metabolic and homoeostatic functions, and pale livers have been associated with nutritional disorders ${ }^{(54)}$. The numerically higher fat content in livers of the FM group, together with significantly fattier hearts, may indicate that the PL fraction of the KM diet $(5 \cdot 0 v \cdot 2 \cdot 6 \%$ in the FM diet) influenced the lipid transport and deposition in the fish organs differently than the FM diet. Increased expression of MTP further indicates enhanced lipid transport ${ }^{(55)}$, and the altered FA composition of the free FA in muscle, which are available for metabolism, indicates that krill meal affected the bioconversion of both saturated, $n-3$ and $n-6$ FA. Burri et al. ${ }^{(56)}$ reported that in young mice, an equimolar dose of EPA and DHA derived from fish oil modulated fewer pathways (e.g. lipid metabolism and the mitochondrial respiratory chain) than a krill oil-supplemented diet. This suggests that krill-derived $n$ - 3 PUFA are more bioactive compared with fish oil.

An interesting observation from the liver microarray analyses was a 2.4-fold higher expression of cadherin-13 (Cdh13) of the KM group. Chd13 is associated with circulating level of the adipocyte-secreted protein adiponectin that has anti-inflammatory potential and plays an important role in metabolic regulation, associated with the fatty liver index in humans ${ }^{(57)}$. The up-regulation of tight junction proteins (connexin, 1.6-fold) indicates improved cell-cell communication of salmon fed krill-supplemented diets, and Willebrords et $a l .{ }^{(58)}$ reported involvement of connexin hemichannels in non-alcoholic steatohepatitis. Among genes shown to have a role in immune surveillance of KM was up-regulation of ladderlectin (three genes, 1.5-1.8 fold) with broad pathogen recognition in rainbow trout ${ }^{(59-61)}$. In addition to liver, dietary krill meal inclusion appeared to improve gut health as ectopic epithelial cells and focal $\mathrm{Ca}$ deposits were not observed in KM. Focal accumulation of $\mathrm{Ca}$ in necrotic tissue (dystrophic calcification) has previously been observed in intestinal inflammation in Atlantic salmon ${ }^{(62)}$, and the presence of ectopic epithelial cells in the intestine has been associated with chronic feed-induced gut inflammation associated with plant-based ingredients ${ }^{(63,64)}$. The level of plant-based ingredients was similar for the FM and KM diets in the present study. Hence, the observed effects could indicate that krill meal may have anti-inflammatory effects or potentially counteract inflammatory processes in the gut.

Salmon farming is the production of high-quality food. Therefore, it is vital that the fillet quality is in accordance with customers' expectations. Visual appearance is the most important property of foods in determining their selection ${ }^{(65)}$, while salmon fillets with insufficient firmness are downgraded, leading to severe economic losses to the farming and processing industries ${ }^{(66)}$. The present study was conducted during autumn, which is the most critical period of the year with regard to 
customer complaints on pale fillet colour, gaping and soft texture, independent of the geographical salmon farming region $^{(67)}$. At the same time, this period is characterised with highest volume of harvested salmon ${ }^{(4)}$.

For salmon fillets, a colour intensity corresponding to SalmoFan colour score of 25 in the posterior standard NQC cutlet meets most customers' demands, while lower scores increase the risk for quality downgrading ${ }^{(68)}$. Krill meal significantly improved the overall colour, and all fillets of the KM group had SalmoFan score $\geq 25$, while $13 \%$ of the FM group had SalmoFan below the general acceptance level $(P=0.03)$. Astaxanthin is the most common carotenoid used for pigmentation of farmed salmon ${ }^{(69)}$, and pale colour of salmon fillets during periods with high growth has been explained by a negative correlation between feed intake and apparent digestibility of astaxanthin ${ }^{(26)}$. Since the TGC and astaxanthin content in muscle were similar for the FM and KM groups, the improved perceived colour could be related to structural variation in muscle proteins, as was observed by Johnston et al. ${ }^{(70)}$. Furthermore, the negative correlation between liver fat content and astaxanthin in skeletal muscle requires further investigation. Dark discoloured spots are major causes to quality downgrading of farmed salmon fillets ${ }^{(71)}$. The KM group had $8 \%$ unit's lower prevalence of dark spots, but the difference was non-significant.

Improved firmness and integrity (less gaping) by supplementing salmon finishing diets with krill meal showed significant correlation with a range of biochemical and molecular factors, supporting that fillet texture is multifactorial, with complex biological interactions. Previous studies have documented that collagen characteristic is a major determinant of salmon fillet firmness ${ }^{(38,72)}$. In the present study, lower presence of single $\alpha$-helix, lower random coil and lower disordered structures in collagen molecules of the KM group suggest higher preservation of collagen native structure in contrast to the FM group. Also, the collagen of the KM group exhibited lower intermolecular cross-links associated with $\beta$-sheets that could be related to the lower helix stabilisation by bonds in which Hyp was involved and to the lower presence of hydrogen bonds. As previously reported, all these findings indicate a more preserved native structure and less aggregated collagen molecule in the KM group than in the FM group ${ }^{(72)}$.

The region of carbohydrates linkage to the collagen molecules has been described to be due to $-\mathrm{C}=\mathrm{O}$ group stretching. As such these may correspond to carbohydrates linked to the collagen molecule by the hydroxyl group reacting with protein carbonyl groups mainly derived from non-enzymatic glycosylation of collagen. The carbohydrates linkage to the collagen molecules has been related to collagen aggregation, mainly at the telopeptide region through the bonds stablished with Arg and Lys amino acids ${ }^{(73)}$. Although salmon from both dietary groups had similar amino acid composition of the collagen molecules, the absorbance in the IR region of carbohydrates was appreciably higher in molecules of the KM group. This would mean increased collagen aggregation at the telopeptide region in comparison with collagen of the FM group. So, it could be stated that the higher native structure preservation of FM collagen molecule is not related to the carbohydrates linked to the telopeptide region. The more aggregated collagen of the
FM group would be responsible for the lower ordered fibrils inter-connections and the more compact and well-defined architecture of the KM group in comparison with the FM group. That is, morphology examination by scanning electron microscopy and secondary structure analyses by Fourier transform IR spectroscopy revealed more ordered collagen architecture of the KM group, in addition to lower single $\alpha$-helix, random coil, intermolecular cross-link and more stable cross-links.

Soft flesh of Atlantic salmon has been associated with myocyte detachment and altered extracellular matrix protein distribution ${ }^{(66)}$. Microarray analyses showed that several genes for proteins involved in cell contacts and adhesion were stimulated in muscle and liver of the KM group, but only one gene (suppressor of cytokine signalling 2) was bookmarked in both tissues at low level of differential expression; otherwise, responses to feeds in the liver and muscle were completely different. Despite small magnitude of transcriptomic changes, the effects of krill meal supplementation were consistent and characterised mainly by up-regulation of genes as compared with the FM group. The largest functional group that responded to feeds in muscle was genes for myofiber proteins where most of them encode different forms of myosin heavy chain. Moreover, myomesin-2 that is a gene encoding a protein responsible for the elastic behaviour of the myocyte ${ }^{(74)}$ showed a 1.5-fold increased expression of the KM group compared with the FM group.

\section{Conclusion}

The present experiment aimed to fill key gaps in the current knowledge on how dietary krill meal supplementation affects fish health and meat quality in Atlantic salmon. The results showed that feeding growing and finishing salmon with diets supplemented with krill meal improved fish health and fillet quality that coincided with up-regulation of immune genes, proteins defining muscle properties and genes involved in cell contacts and adhesion, altered FA metabolism and fat deposition, and improved gut health. Higher fillet firmness coincided with more compact and well-organised collagen architecture and predominance of the native collagen structure.

\section{Acknowledgements}

The authors thank the staff at LetSea AS for farming the fish and for skilful technical assistance.

This work was funded by Aker Biomarine Antarctic AS, Oslo, Norway.

T. M. as a project leader contributed to the formulation of the research questions, design of the study and analyses. H. M. M. and J. B. were responsible for the connective tissue analyses. T. L. contributed to planning of the experiment and analyses of flesh quality. H. H. was responsible for histopathology analyses. C. C. L. and A. K. were responsible for the gene expression analyses. B. H. and O. H. R. were responsible for diet formulation. B. R. was responsible for interpretation of fatty acid analyses. R. J.-G. and M. T. B. contributed to planning of the experiment, sampling and analyses. T. B.-S. contributed with 
design and analytical approach. All authors contributed with writing and editing the article.

The authors declare that there are no conflicts of interest.

\section{References}

1. Green K (2016) Fishmeal and fish oil facts and figures. https:// www.seafish.org/media/publications/SeafishFishmealandFish OilFactsandFigures_201612.pdf (accessed September 2019)

2. New MB \& Wijkström UN (2002) Use of Fishmeal and Fish Oil in Aquafeeds: Further Thoughts on the Fishmeal Trap. Rome: Food and Agriculture Organization of the United Nations.

3. Ytrestøyl T, Aas TS \& Åsgård T (2015) Utilisation of feed resources in production of Atlantic salmon (Salmo salar) in Norway. Aquaculture 448, 365-374.

4. Norwegian Seafood Federation (2019) Akvafakta. https:// akvafakta.no/wp-content/uploads/Maned/siste.pdf (accessed September 2019)

5. Xie D, Gong M, Wei W, et al. (2019) Antarctic krill (Euphausia superba) oil: a comprehensive review of chemical composition, extraction technologies, health benefits, and current applications. Compr Rev Food Sci Food Saf 18, 514-534.

6. Hertrampf JW \& Piedad-Pascual F (2012) Handbook on Ingredients for Aquaculture Feeds. Berlin: Springer Science \& Business Media.

7. Tou JC, Jaczynski J \& Chen Y-C (2007) Krill for human consumption: nutritional value and potential health benefits. Nutr Rev 65, 63-77.

8. Köhler A, Sarkkinen E, Tapola N, et al. (2015) Bioavailability of fatty acids from krill oil, krill meal and fish oil in healthy subjects - a randomized, single-dose, cross-over trial. Lipids Health Dis 14, 19.

9. Everson I (2008) Krill: Biology, Ecology and Fisheries. Hoboken, NJ: John Wiley \& Sons.

10. Burri L \& Nunes A (2016) Benefits of including krill meal in shrimp diets. World Aquacult 19-23.

11. Storebakken T (1988) Krill as a potential feed source for salmonids. Aquaculture 70, 193-205.

12. Anderson JS (1997) The Evaluation of Air-dried Whole Krill Meal as a Dietary Protein Supplement for Juvenile Chinook Salmon (Oncorhynchus Tshawytscha). Canadian Technical Report of Fisheries and Aquatic Sciences no. 2148. Science Branch, Pacific Region, West Vancouver, B.C.: Department of Fisheries \& Oceans.

13. Kubitza F \& Lovshin LL (1997) Effects of initial weight and genetic strain on feed training largemouth bass Micropterus salmoides using ground fish flesh and freeze dried krill as starter diets. Aquaculture 148, 179-190.

14. Olsen RE, Suontama J, Langmyhr E, et al. (2006) The replacement of fish meal with Antarctic krill, Euphausia superba in diets for Atlantic salmon, Salmo salar. Aquacult Nutr 12, 280-290.

15. Suontama J, Kiessling A, Melle W, et al. (2007) Protein from Northern krill (Thysanoessa inermis), Antarctic krill (Euphausia superba) and the Arctic amphipod (Themisto libellula) can partially replace fish meal in diets to Atlantic salmon (Salmo salar) without affecting product quality. Aquacult Nutr 13, 50-58.

16. Hatlen B, Berge K, Nordrum S, et al. (2017) The effect of low inclusion levels of Antarctic krill (Euphausia superba) meal on growth performance, apparent digestibility and slaughter quality of Atlantic salmon (Salmo salar). Aquacult Nutr 23, 721-729.

17. Aas TS, Ytrestøyl T \& Åsgård T (2019) Utilization of feed resources in the production of Atlantic salmon (Salmo salar) in Norway: an update for 2016. Aquacult Rep 15, 100216.
18. Thomassen M, Gudding R, Norberg B, et al. (2007) Aquaculture Research: From Cage to Consumption. Oslo: Research Council of Norway.

19. Rasmussen RS (2001) Quality of farmed salmonids with emphasis on proximate composition, yield and sensory characteristics. Aquacult Res 32, 767-786.

20. Mørkøre T \& Rørvik K-A (2001) Seasonal variations in growth, feed utilisation and product quality of farmed Atlantic salmon (Salmo salar) transferred to seawater as $0+$ smolts or $1+$ smolts. Aquaculture 199, 145-157.

21. Folkestad A, Rørvik KA, Kolstad K, et al. (2008) Growth rates of individual farmed Atlantic salmon Salmo salar $\mathrm{L}$. influence the texture of raw and smoked fillets. Aquacult Res 39, 329-332.

22. Koteng DF (1992) Markedsundersøkelse norsk laks (Market Investigation Norwegian salmon). Prosjekt God Fisk. Bergen: Fiskerinæringens Landsforening (FHL) (In Norwegian).

23. Michie I (2001) Causes of downgrading in the salmon industry. In Farmed Fish Quality, pp. 129-136 [SC Kestin and P Warris, editors]. Oxford: Blackwell Science.

24. National Research Council (2011) Nutrient Requirements of Fish and Shrimp. Washington, DC: The National Academies Press. https://doi.org/10.17226/13039

25. Thivend P, Mercier C \& Guilbot A (1972) Determination of starch with glucoamylase. In General Carbohydrate Method, pp. 100-105 [R Whistler and J Bemiller, editors]. New York: Academic Press.

26. Ytrestøyl T, Struksnæs G, Rørvik K-A, et al. (2006) Astaxanthin digestibility as affected by ration levels for Atlantic salmon, Salmo salar. Aquaculture 261, 215-224.

27. Kousoulaki K, Mørkøre T, Nengas I, et al. (2016) Microalgae and organic minerals enhance lipid retention efficiency and fillet quality in Atlantic salmon (Salmo salar L.). Aquaculture 451, 47-57.

28. Wall T \& Bjerkas E (1999) A simplified method of scoring cataracts in fish. Bull Eur Ass Fish Pathol 19, 162-165.

29. Tietz NW (1995) Clinical Guide to Laboratory Tests, 3rd ed. Philadelphia, PA: WB Saunders Company.

30. Krasnov A, Timmerhaus G, Afanasyev S, et al. (2011) Development and assessment of oligonucleotide microarrays for Atlantic salmon (Salmo salar L.). Comp Biochem Physiol D Genomics Proteomics 6, 31-38.

31. Erikson U, Bye G \& Oppedal K (2009) Fastere filet-industritest og opplæring (Firmer fillet - industry test and training). SINTEF rapport no. SFH80. Trondheim: SINTEF (In Norwegian).

32. Mørkøre T \& Einen O (2003) Relating sensory and instrumental texture analyses of Atlantic salmon. J Food Sci 68, $1492-1497$.

33. Norges Standardiseringsforbund (1994) Atlantic salmon Reference sampling for quality measurements. In NS9401. Oslo: Norges Standardiseringsforbund.

34. Folch J, Lees M \& Sloane Stanley GH (1957) A simple method for the isolation and purification of total lipides from animal tissues. J Biol Chem 226, 497-509.

35. Mason ME, Eager ME \& Waller GR (1964) A procedure for the simultaneous quantitative determination of glycerol and fatty acid contents of fats and oils. Anal Chem 36, 587-590.

36. Bou M, Berge GM, Baeverfjord G, et al. (2017) Low levels of very-long-chain $n$-3 PUFA in Atlantic salmon (Salmo salar) diet reduce fish robustness under challenging conditions in sea cages. J Nutr Sci $\mathbf{6}$, e32.

37. Borderias AJ \& Montero P (1985) Changes in fish muscle collagen during frozen storage. In Storage Lives of Chilled and Frozen Products, Proceedings of Meetings of Commissions C2 and D3 of IIR, pp. 65-71 [International Institute of Refrigeration, editors]. Paris: International Institute of Refrigeration. 
38. Moreno H, Montero M, Gómez-Guillén M, et al. (2012) Collagen characteristics of farmed Atlantic salmon with firm and soft fillet texture. Food Chem 134, 678-685.

39. Sigurgisladottir S, Hafsteinsson H, Jonsson A, et al. (1999) Textural properties of raw salmon fillets as related to sampling method. J Food Sci 64, 99-104.

40. Nortvedt R (1996) Anvendelse av kjemometri innen forskning og industri (Application of Chemometrics in Research and Industry). Oslo: Tidsskriftforlaget Kjemi.

41. Eckhoff KM, Aidos I, Hemre G-I, et al. (1998) Collagen content in farmed Atlantic salmon (Salmo salar, L.) and subsequent changes in solubility during storage on ice. Food Chem 62, 197-200.

42. Kirschner C, Ofstad R, Skarpeid H-J, et al. (2004) Monitoring of denaturation processes in aged beef loin by Fourier transform infrared microspectroscopy. J Agric Food Chem 52, 3920-3929.

43. Iversen A \& Kosmo J (2004) Kan vekstindeksene sammenlignes (Can growth indices be compared). Norsk Fiskeoppdrett no. 4/ 2004. Bergen

44. Iversen A, Hermansen $\varnothing$, Nystøyl R, et al. (2017) Kostnadsutvikling i lakseoppdrett-med fokus på fôr-og lusekostnader (Cost development in salmon farming - focusing on feed and lice costs). Nofima rapportserie no. 37/2018. Tromsø: Nofima.

45. Mørkøre T, Vallet J, Cardinal M, et al. (2001) Fat content and fillet shape of Atlantic salmon: relevance for processing yield and quality of raw and smoked products. J Food Sci $\mathbf{6 6}$, 1348-1354.

46. Alne H, Oehme M, Thomassen M, et al. (2011) Reduced growth, condition factor and body energy levels in Atlantic salmon Salmo salar L. during their first spring in the sea. Aquacult Res 42, 248-259.

47. Dessen J-E, Weihe R, Hatlen B, et al. (2017) Different growth performance, lipid deposition, and nutrient utilization in inseason (S1) Atlantic salmon post-smolt fed isoenergetic diets differing in protein-to-lipid ratio. Aquaculture 473, 345-354.

48. Rørvik KA, Dessen JE, Åsli M, et al. (2018) Low body fat content prior to declining day length in the autumn significantly increased growth and reduced weight dispersion in farmed Atlantic salmon Salmo salar L. Aquacult Res 49, 1944-1956.

49. De Pitta C, Biscontin A, Albiero A, et al. (2013) The Antarctic krill Euphausia superba shows diurnal cycles of transcription under natural conditions. PLOS ONE 8, e68652.

50. LumeijJ \& Westerhof I (1987) Blood chemistry for the diagnosis of hepatobiliary disease in birds. A review. Vet Quart 9 , 255-261.

51. Hansen JØ, Penn M, Øverland M, et al. (2010) High inclusion of partially deshelled and whole krill meals in diets for Atlantic salmon (Salmo salar). Aquaculture 310, 164-172.

52. Sandnes K, Lie $\varnothing \&$ Waagb $\varnothing \mathrm{R}$ (1988) Normal ranges of some blood chemistry parameters in adult farmed Atlantic salmon, Salmo salar. J Fish Biol 32, 129-136.

53. Marchesini G, Moscatiello S, Di Domizio S, et al. (2008) Obesity-associated liver disease. J Clin Endocrinol Metab $\mathbf{9 3}$, 74-80.

54. Tacon AGJ (1992) Nutritional Fish Pathology. Morphological Signs of Nutrient Deficiency and Toxicity in Farmed Fish. FAO Fish Technical Paper 330, 75.

55. Feingold KR \& Grunfeld C (2018) Introduction to lipids and lipoproteins. In Endotext [Internet]. MDText. com, Inc.

56. Burri L, Berge K, Wibrand K, et al. (2011) Differential effects of krill oil and fish oil on the hepatic transcriptome in mice. Front Genet 2, 45.

57. Nicolas A, Aubert R, Bellili-Munoz N, et al. (2017) T-cadherin gene variants are associated with type 2 diabetes and the fatty liver index in the French population. Diabetes Metab 43, 33-39.

58. Willebrords J, Cogliati B, Pereira IVA, et al. (2017) Inhibition of connexin hemichannels alleviates non-alcoholic steatohepatitis in mice. Sci Rep 7, 8268.

59. Reid A, Young K \& Lumsden J (2011) Rainbow trout Oncorbynchus mykiss ladderlectin, but not intelectin, binds viral hemorrhagic septicemia virus IVb. Dis Aquat Organ 95, 137-143.

60. Young KM, Russell S, Smith M, et al. (2007) Bacterial-binding activity and plasma concentration of ladderlectin in rainbow trout (Oncorbynchus mykiss). Fish Shellish Immunol 23, 305-315.

61. Russell S, Young K, Smith M, et al. (2008) Cloning, binding properties, and tissue localization of rainbow trout (Oncorbynchus mykiss) ladderlectin. Fish Shellfish Immunol 24, 669-683.

62. Waagbø R, Berntssen M, Danielsen T, et al. (2013) Feeding Atlantic salmon diets with plant ingredients during the seawater phase - a full-scale net production of marine protein with focus on biological performance, welfare, product quality and safety. Aquacult Nutr 19, 598-618.

63. Bjørgen H, Koppang EO, Gunnes G, et al. (2018) Ectopic epithelial cell clusters in salmonid intestine are associated with inflammation. J Fish Dis 41, 1031-1040.

64. Dale OB, Tørud B, Kvellestad A, et al. (2009) From chronic feed-induced intestinal inflammation to adenocarcinoma with metastases in salmonid fish. Cancer Research 69, 4355-4362.

65. Simpson K, Katayama T, Chichester C, et al. (1981) Carotenoids as Colorants and Vitamin A Precursors. New York: Academic Press.

66. Torgersen JS, Koppang EO, Stien LH, et al. (2014) Soft texture of Atlantic salmon fillets is associated with glycogen accumulation. PLOS ONE 9, e85551.

67. Nordberg M (2018) Seasonal variation in fillet quality of Atlantic salmon (Salmo salar). Master Thesis, Norwegian University of Life Sciences, Ås.

68. Anderson S (2000) Salmon color and the consumer. Microbehavior and Macroresults: Proceedings of the Tenth Biennial Conference of the International Institute of Fisheries Economics and Trade, 10-14 July 2000, Corvallis, OR, USA. https://ir.library.oregonstate.edu/concern/conference_ proceedings_or_journals/9s1616848

69. Torrissen O, Hardy R \& Shearer K (1989) Pigmentation of salmonids-carotenoid deposition and metabolism. CRC Crit Rev Aquat Sci 1, 209-225.

70. Johnston IA, Alderson R, Sandham C, et al. (2000) Muscle fibre density in relation to the colour and texture of smoked Atlantic salmon (Salmo salar L.). Aquaculture 189, 335-349.

71. Mørkøre T, Larsson T, Kvellestad AS, et al. (2015) Mørke flekker i laksefilet. Kunnskapsstatus og tiltak for å begrense omfanget (Dark spots in salmon fillets. Knowledge status and measures to reduce prevalence). Nofima rapportserie no. 34/2015. Tromsø: Nofima.

72. Moreno H, Jacq C, Montero M, et al. (2016) Effect of selective breeding on collagen properties of Atlantic salmon (Salmo salar L.). Food Chem 190, 856-863.

73. Priego-Capote F, Scherl A, Müller M, et al. (2010) Glycation isotopic labeling with 13C-reducing sugars for quantitative analysis of glycated proteins in human plasma. Mol Cell Proteomics 9, 579-592.

74. Tskhovrebova L \& Trinick J (2012) Making muscle elastic: the structural basis of myomesin stretching. PLOS Biol 10, e1001264. 